University of Nebraska - Lincoln

DigitalCommons@University of Nebraska - Lincoln

2007

\title{
A world revision of the Pycnostigminae (Cynipoidea: Figitidae) with descriptions of seven new species
}

\author{
Matthew L. Buffington \\ Smithsonian Institution, matt.buffington@ars.usda.gov \\ Simon van Noort \\ Iziko South African Museum
}

Follow this and additional works at: https://digitalcommons.unl.edu/systentomologyusda

Part of the Entomology Commons

Buffington, Matthew L. and Noort, Simon van, "A world revision of the Pycnostigminae (Cynipoidea: Figitidae) with descriptions of seven new species" (2007). USDA Systematic Entomology Laboratory. 70. https://digitalcommons.unl.edu/systentomologyusda/70

This Article is brought to you for free and open access by the Entomology Collections, Miscellaneous at DigitalCommons@University of Nebraska - Lincoln. It has been accepted for inclusion in USDA Systematic Entomology Laboratory by an authorized administrator of DigitalCommons@University of Nebraska - Lincoln. 


\title{
A world revision of the Pycnostigminae (Cynipoidea: Figitidae) with descriptions of seven new species
}

\author{
M.L. BUFFINGTON ${ }^{1} \&$ S. VAN NOORT ${ }^{2}$ \\ ${ }^{1}$ Systematic Entomology Lab, USDA, clo Smithsonian NMNH, 10 ${ }^{\text {th }}$ \& Constitution Ave NW, Washington DC 20013. \\ E-mail: mbuffington@sel.barc.usda.gov \\ ${ }^{2}$ Natural History Division, Iziko South African Museum, PO Box 61, Cape Town, 8000, South Africa
}

\section{Table of contents}

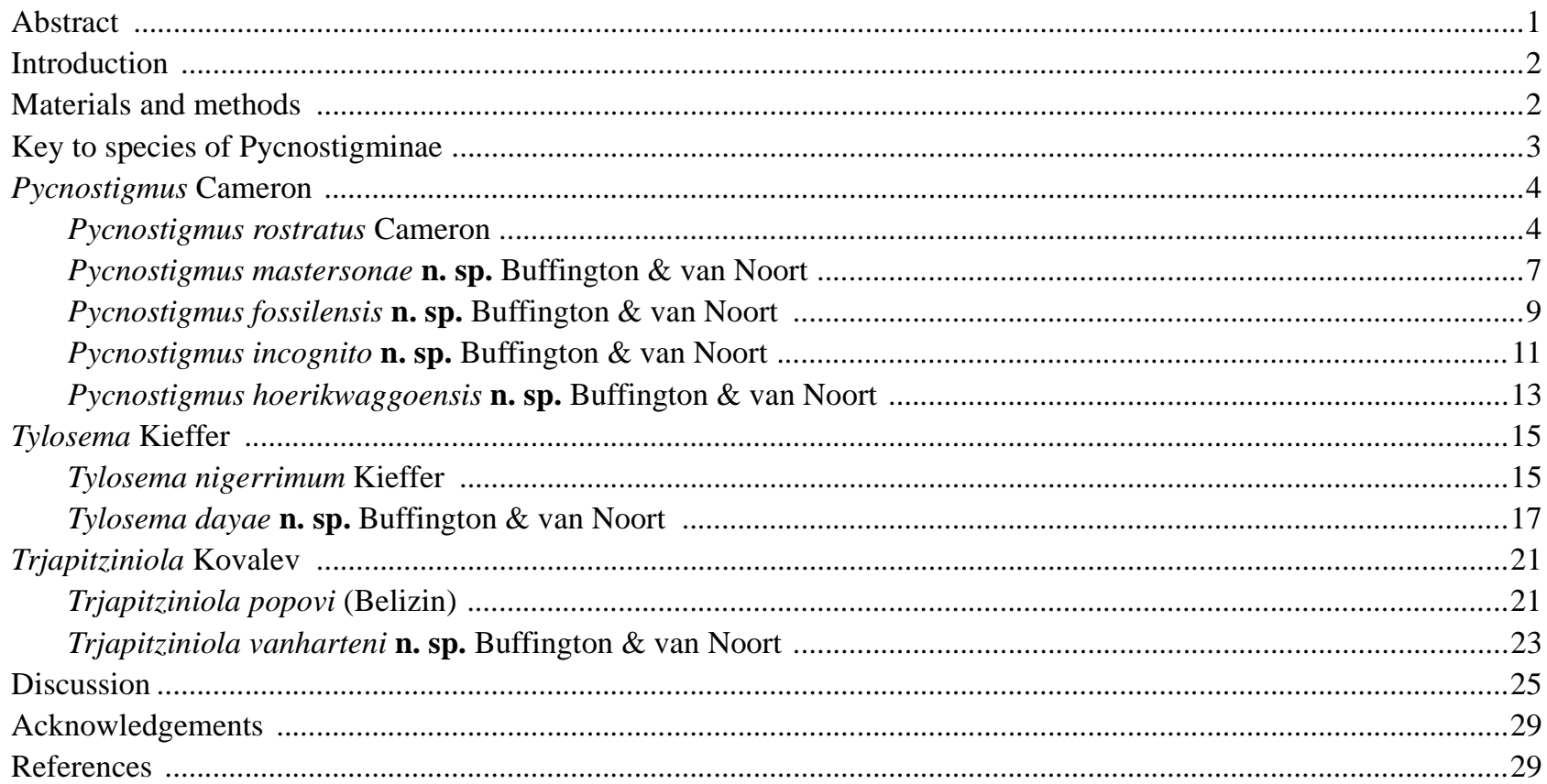

\begin{abstract}
Pycnostigmus rostratus Cameron, 1905, is redescribed and four new species of Pycnostigmus are described: $P$. mastersonae Buffington \& van Noort, new species; P. incognito Buffington \& van Noort, new species; P. fossilensis Buffington \& van Noort, new species; and P. hoerikwaggoensis Buffington \& van Noort, new species. Pycnostigmus mastersonae is the only known species of Cynipoidea with a metallic sheen on the head and mesosoma. A redescription of Tylosema nigerrimum Kieffer, 1905, is provided as well as the description of two new species: Tylosema dayae Buffington \& van Noort, new species and Tylosema ronquisti Buffington \& van Noort, new species. The discovery of two new species of Tylosema in South Africa is noteworthy since the only previously known species, T. nigerrimum Kieffer, is from Algeria. A redescription of Trjapitziniola popovi (Belizin 1951) is provided as well as the description of one new species: Trjapitziniola vanharteni Buffington \& van Noort, new species. Trjapitziniola vanharteni was collected in the United Emirates Republic, which extends the distribution of Trjapitziniola well into the Arabian Penninsula. An online key to World species of Pycnostigminae and images are available at www.waspweb.org/Cynipoidea/Figitidae/Pycnostigminae/ index.htm, and images of all species contained within this paper are available from http://morphbank.net.
\end{abstract}


Key words: Pycnostigmus, Tylosema, Trjapitziniola, Pycnostigminae, Figitidae, Cynipoidea, Hymenoptera, new species, redescription

\section{Introduction}

The Pycnostigminae were originally thought to be part of the synergine complex of inquiline gall wasps (Cynipidae) (Cameron 1905; Weld 1952). Rasnitsyn (1980) was the first to classify the group as belonging to the Figitidae (Ronquist 1995). The phylogeny of Figitidae presented in Ronquist (1999) recovered the pycnostigmines nested deeply within the Figitidae as the sister group to Eucoilinae. Ronquist (1999) speculated on the possibility that, given the unique scutellar morphology of Trjapitziniola Kovalev (scutellum modified into a 'polished plate'), the pycnostigmines might be apomorphic Eucoilinae. Fontal-Cazalla et al. (2002) and Buffington (2000) hypothesized that the pycnostigmines are monophyletic and sister to Eucoilinae. Given these data, it is not likely that the pycnostigmines are nested within Eucoilinae. Furthermore, no pycnostigmines possess the uniquely derived scutellar plate, with the associated glandular release pit, that all Eucoilinae possess (Fontal-Cazalla et al. 2002). Though hosts are unknown for Pycnostigminae, the phylogeny of Figitidae in Ronquist (1999) suggests the likely hosts would be Diptera. The subfamily has been incorrectly spelled in the past as 'Pycnostigmatinae'; Ronquist (1999) justified the correct suffix formation we use here.

To date, Pycnostigmus, Trjapitziniola and Tylosema were monotypic genera. Cameron's (1905) original description of Pycnostigmus states the type specimen of P. rostratus is deposited in the South African Museum, Cape Town, and does not mention any other specimens. Weld (1952) stated that the type specimen is in the British Museum (i.e. The Natural History Museum, London), and does not reference the South African Museum specimen. The specimen of $P$. rostratus in Cape Town bears a label in Cameron's handwriting 'Pycnostigmus rostratus Cam. Type Cape Town', and was collected in '9/87' [September, 1887]. This collection data matches the collection data published in the original description. Based on the specimen label data and the collection data published in the original description, the specimen in the South African Museum must be the holotype of Pycnostigmus rostratus Cameron (article 73.1.1, ICZN 2000). Thus, the specimen in the Natural History Museum, London, is considered paratype (see 'additional material' under P. rostratus). The validity of Tylosema Kieffer has not been questioned; the type of Tylosema nigerrimum Kieffer is in the Museum National d'Histoire Naturelle, Paris, France. The type species of Trjapitziniola Kovalev is Tr. popovi (Belizin 1951) (by original designation and monotypy), a species originally placed in Tylosema. Based on the unique morphology on the dorsal surface of the scutellum, Kovalev (1995) removed Tr. popovi from Tylosema and placed it in his newly described Trjapitziniola. The condition of the type of Tr. popovi is poor and could not be transported to either author of this paper for examination (O. Kovalev, pers. comm.); ergo, the redescription of Tr. popovi is based on material housed in the ZMAS that is conspecific with the type. The holotype of Trjapitziniola popovi is in the Zoological Museum, Academy of Sciences, St. Petersburg, Russia.

\section{Materials and methods}

Specimens were examined using a Wild M-5 stereomicroscope with incandescent and fluorescent light sources. Images for plates were acquired through an EntoVision micro-imaging system. This system included a Leica M16 zoom lens attached to a JVC KY-75U 3-CCD digital video camera that fed image data to a notebook computer. The program Cartograph 5.6.0 was then used to merge an image series (representing typically 30 focal planes) into a single in-focus image. Lighting was achieved using techniques summarized in Buffington et al. (2005). Morphological terminology follows that of Fontal-Cazalla et al. (2002) and cuticular surface terminology follows Harris (1979). All images presented in this paper are freely available through http://morphbank.net using the link to individual collections found at the end of each species description/redescription. 
CASC California Academy of Sciences, San Francisco. B. Zuparko, curator.

MNHN Museum National d'Histoire Naturelle, Paris. C. Villemant, curator.

NHML The Natural History Museum, London. S. Ryder, curator.

SAMC Iziko South African Museum, Cape Town. S. van Noort, curator.

ULMZ University of Lund, Museum of Zoology, Lund, Sweden. R. Danielsson, curator.

USNM National Museum of Natural History, Washington, D.C. M. Buffington, curator.

ZMAS Zoological Museum, Academy of Sciences, St. Petersburg, Russia. O. Kovalev, curator.

Identification of Pycnostigminae

Species of pycnostigmines are readily separated from all other Figitidae by the presence of a pseudostigma on the forewing (e.g., Figs $2 \mathrm{~A} \& 2 \mathrm{D}$ ). The pseudostigma is merely pigmentation within the confines of the marginal cell. Upon careful examination, an observer will see the pycnostigmine marginal cell as enclosing a circular area instead of the typical triangular area of all other Cynipoidea. Diagnostic characters used to separate the genera and species of Pycnostigminae are given in the key below.

\section{Key to species of Pycnostigminae}

1a. Notaulices complete from anterior margin of mesoscutum (at junction with pronotum) to posterior margin (at junction with scutellum); parascutal impression present; female with more than 10 flagellomeres...... 2

1b. Notaulices incomplete, not reaching the pronotum but present midway across mesoscutum and continuing to junction with scutellum; parascutal impression absent; female with 10 flagellomeres Tylosema, 7

2a. Scutellum in lateral view evenly rounded. Pycnostigmus, 3

2b. Scutellum in lateral view with a distinct angle, resulting in a postero-dorsal flattened area.

Trjapitziniola, 9

3a. Head, mesosoma and coxae metallic green-gold. Pycnostigmus mastersonae

3b. Head, mesosoma and coxae non-metallic 4

4a. Pronotum foveolate and rugulose Pycnostigmus rostratus

4b. Pronotum weakly to strongly carinate, not foveolate 5

5a. Disk of scutellum smooth and polished in center Pycnostigmus fossilensis

5b. Disk of scutellum partially to entirely rugose...... 6

6a. Mesopleuron with numerous strigae; pronotum strongly carinate; disk of scutellum carinate posteriorly... Pycnostigmus hoerikwaggoensis

6b. Mesopleuron smooth with few strigae; pronotum smooth with a few weak carinae; disk of scutellum with a single dominant carina present around the perimeter of disk Pycnostigmus incognito

7a. Disk of scutellum entirely smooth; posterior margin of scutellum lacking a distinct carinaTylosema dayae

7b. Disk of scutellum smooth at center, rugose on lateral and posterior edges; posterior margin of disk of scutellum with a distinct carina ......

8a. Lateral aspect of pronotum smooth; mesoscutum smooth and lacking setae.... Tylosema ronquisti

8b. Lateral aspect of pronotum rugulose/areolate; mesoscutum distinctly shagreened with scattered setae Tylosema nigerrimum

9a. Mesopleuron striate anteriorly, gradually becoming smooth posteriorly; ventral portion of metapleuron crenulate; ventro-posterior aspects of propodeum glabrous.

Trjapitziniola popovi

9b. Mesopleuron entirely striate; ventral portion of metapleuron smooth; ventro-posterior aspects of propodeum setose. Trjapitziniola vanharteni 


\section{Pycnostigmus Cameron}

(Figs 1-6)

\section{Pycnostigmus rostratus Cameron}

(Figs 1-2)

Pycnostigmus rostratus Cameron 1905: 20-21. Type species by monotypy.

Redescription. Holotype FEMALE. Head. Shagreened and substantially setose (frons, occiput, cheeks) (Figs $1 \mathrm{E} \& 2 \mathrm{E})$. Antenna entirely dark brown/black, scape $1.75 \mathrm{x}$ length of radicle, short appressed setae on all 16 flagellomeres, moniliform.

Mesosoma. Lateral surface of pronotum densely rugulose and pitted; evenly covered in moderately long setae (Figs 1B \& 2B). Mesopleuron striate except for small area immediately ventrad of mesopleural triangle, and an additional portion immediately dorsal of mesocoxa; dorsal and ventral margins of mesopleural triangle clearly visible, center of triangle setose (Figs 1B \& 2B). Mesoscutum weakly pitted with small punctures and sparsely setose; cuticle between punctures shiny; notaulices complete, originating at anterior end of parascutal impression; posterior convergence point of notaulices with a small subquadrate, shiny portion of the mesoscutum indented (Figs 1C \& 2C). Disk of scutellum strongly rugose and deeply pitted, setose along posterior margin; sides not marked by a distinct carina, curving ventrally (Figs $1 \mathrm{C} \& 2 \mathrm{C}$ ); scutellar ridge that separates scutellar fovea often extending to small spine along posterior margin of scutellum.

Metapleural-propodeal complex. Entire metapleuron covered in long, thin setae (Figs 1B \& 2B). Propodeum sparsely covered by long setae; cuticle deeply rugulose across entire propodeum. Nucha extended posteriorly, deeply striate (Figs 1A, 2A, 1C \& 2C).

Metasoma. Petiole about as long as deep, deeply striate. Syntergum (T2+T3) shiny and smooth; posterior portion of T-3-4 with a brush of setae (Figs 1A \& 2A). Entire metasoma, in lateral view, about as long as deep.

Wings. Pseudostigma weakly pigmented, marginal cell visible (Figs 1D \& 2D).

Legs. Femora and tibiae black; long setae present. Tarsomeres brown, covered in short, appressed setae (Figs 1A \& 2A).

MALE. As in female except: 18 antennal flagellomeres present; length of metasoma 1.67x depth.

Diagnosis. Separated from $P$. mastersonae by the head and mesosoma being non-metallic; from $P$. fossilensis by having the disk of the scutellum completely rugose (center smooth in P. fossilensis); from $P$. incognito by having the mesopleuron mostly striate (almost entirely smooth in $P$. incognito); from $P$. hoerikwaggonensis by having the lateral aspect of the pronotum areolate (striate in $P$. hoerikwaggonensis).

Distribution. South Africa: Western Cape (Fig. 13).

Material examined. Holotype: [first label] Cape T, 9/87 [Cape Town, September, 1887], [second label] SAM-HYM-P002866, [third label, in Cameron's handwriting] Pycnostigmus rostratus Cam. Type Cape Town (see inset Fig. 1A for labels). The type is a female, in good condition (c.f. Fig. 1), having been remounted on a card by M. Sporrong (Sweden). Deposited in SAMC.

Additional material. Paratype: SOUTH AFRICA. [first label] Type (NHML type label with red ring), [second label] B.M. Type Hym. 7. 1., [third label, in Cameron's handwriting] Pycnostigmus rostratus Cam. Type Cape Town, [fourth label] Cameron Coll. 1906-138. The type is in moderate condition, with the head plus mesosoma together and mounted separately from the metasoma. Deposited in NHML. Western Cape Province. Koeberg Nature Reserve, 3337.622'S 18²4.259'E, 8 Aug-5 Sept 1997, S van Noort, Malaise trap KO97-M07, West Coast Strandveld, (1 female) [SAMC]; Koeberg Nature Reserve, 333․ $322^{\prime} \mathrm{S} 18^{\circ} 24.259^{\prime} \mathrm{E}$, 8 Aug-5 Sept 1997, S van Noort, Malaise trap KO97-M08, West Coast Strandveld, SAM-HYM-P024713 (1 female) [SAMC]; West Coast Fossil Park (5.5 km 290 ${ }^{\circ} \mathrm{W}$ Langebaanweg) 32 $57.402^{\prime} \mathrm{S} 18^{\circ} 05.438^{\prime} \mathrm{E}$, 4-11 Sept 2002, S van Noort, Malaise trap, LW02-R5-M12, rehabilitated mine dump, SAM-HYM-P024398 (determined by F. Ronquist, 2005) (1 female) [SAMC]; Jacobsbaai, N of Saldanha Bay, 3258’S 1754'E, P.T.O., 
(A)
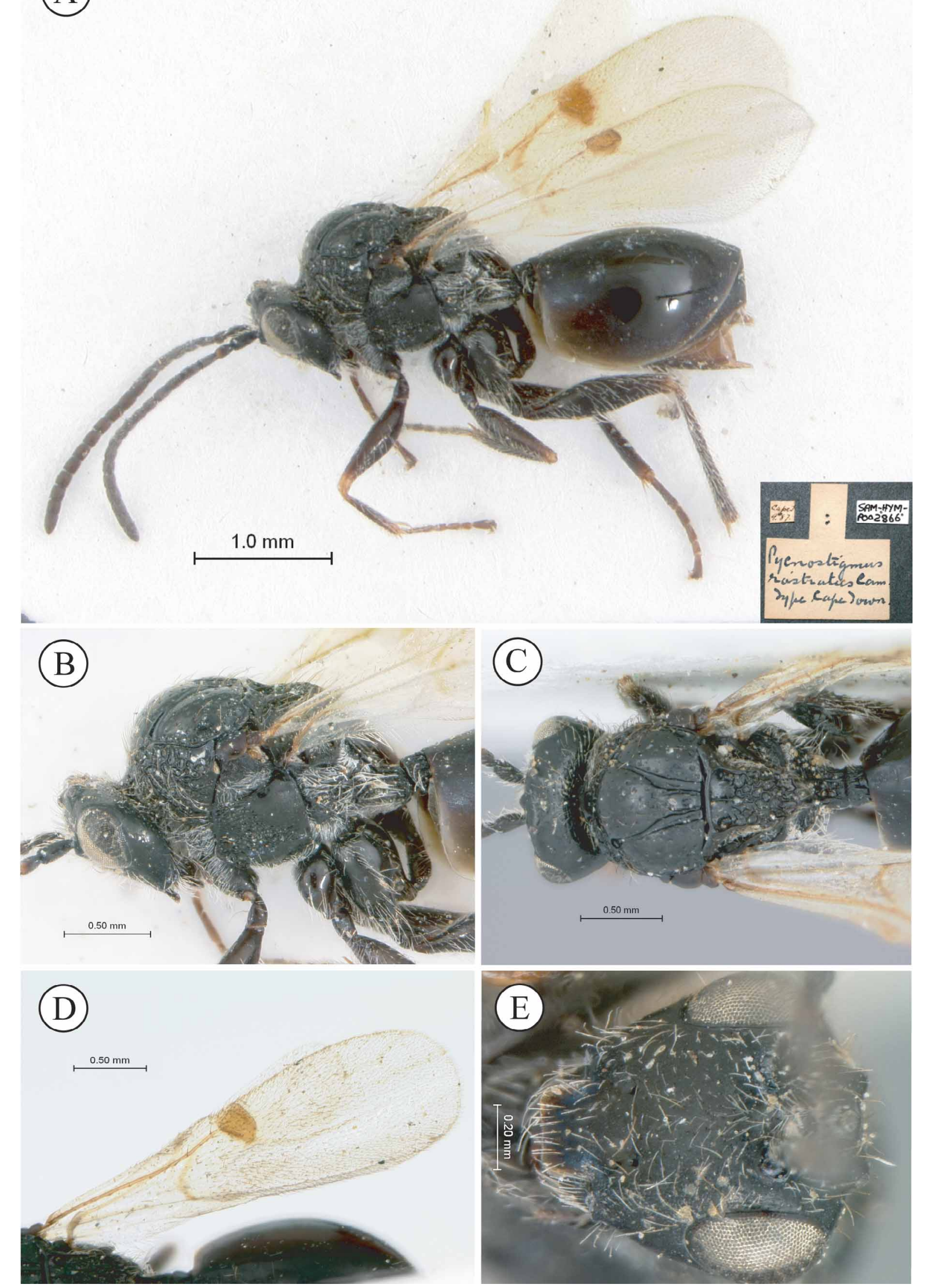

FIGURE 1. Pycnostigmus rostratus Cameron, holotype specimen, female. A, habitus; inset, specimen labels. B, head and mesosoma, lateral view. C, head and mesosoma, dorsal view. D, left forewing. E, head, anterior view. 

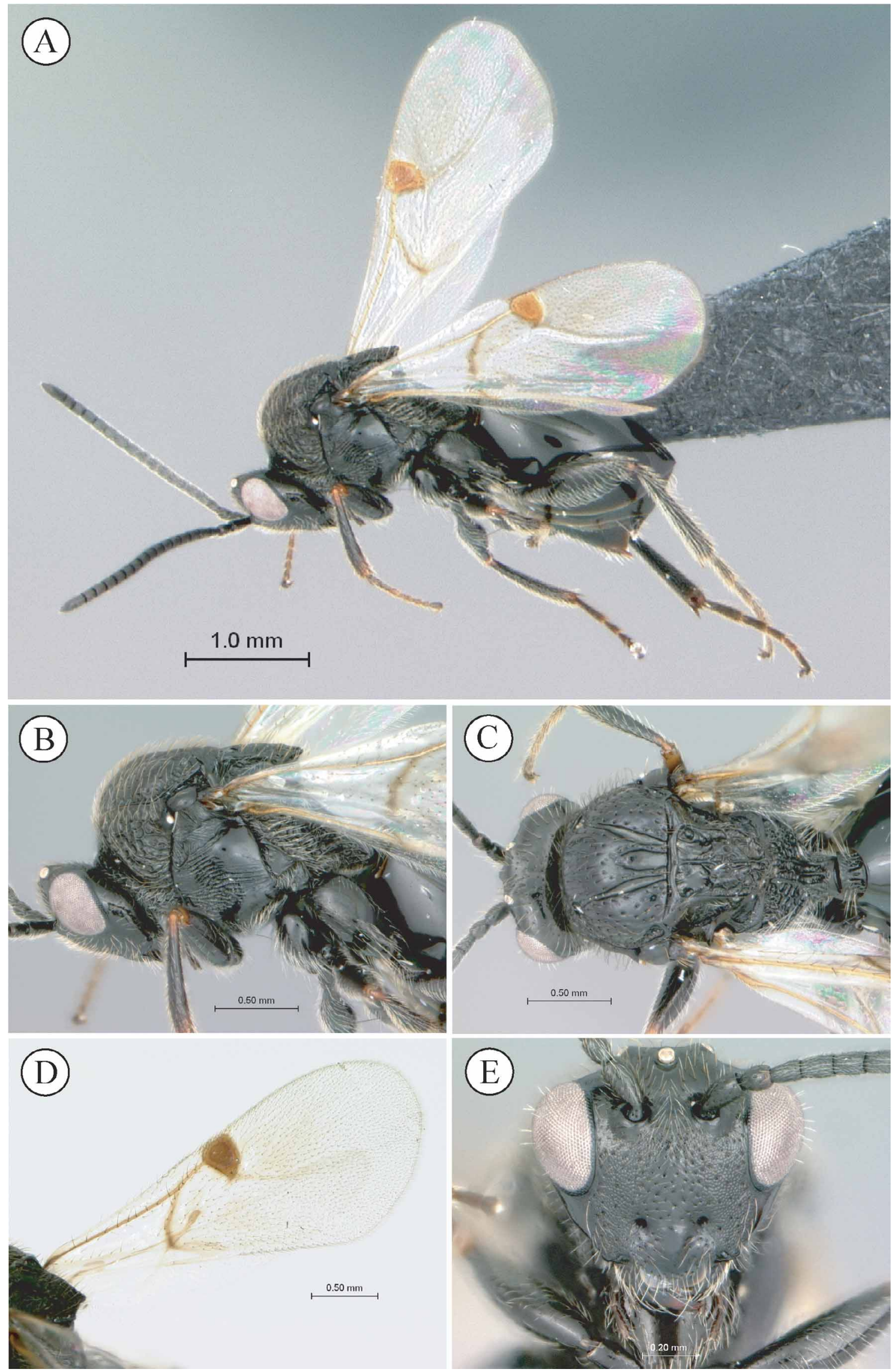

FIGURE 2. Pycnostigmus rostratus Cameron, non-type specimen, female. A, habitus. B, head and mesosoma, lateral view. C, head and mesosoma, dorsal view. D, left forewing. E, head, anterior view. 
HG Robertson, West Coast Strandveld ex pitfall trap, SAM-HYM-P024396 (1 female); West Coast Fossil Park, (3 km 270 ${ }^{\circ} \mathrm{W}$ Langebaanweg), 32 ${ }^{\circ} 58.445^{\prime} \mathrm{S} 18^{\circ} 07.236 ' \mathrm{E}, 18-25$ Sept 2002 , S van Noort, Malaise trap LW02-N3-M39, Sand Plain Fynbos (4 female, 2 male) [SAMC]; Anyskop Farm, (5.5 km 290 ${ }^{\circ} \mathrm{W}$ Langebaanweg) $32^{\circ} 57.394 ' \mathrm{~S} 18^{\circ} 05.324^{\prime} \mathrm{E}, 16-23$ Oct 2002, S van Noort, Malaise trap LW02-N7-M115, Sand Plain Fynbos ( 1 female, 1 male) [USNM], West Coast Fossil Park, ( $3 \mathrm{~km} 270^{\circ} \mathrm{W}$ Langebaanweg) $32^{\circ} 58.445^{\prime} \mathrm{S}$ $18^{\circ} 07.236^{\prime}$ E, 18-25 Sept 2002, S van Noort, Malaise trap LW02-N3-M39, Sand Plain Fynbos (1 male) [SAMC]; Anyskop Farm, (5.5 km 290 ${ }^{\circ} \mathrm{W}$ Langebaanweg) 32 $57.301^{\prime} \mathrm{S} 18^{\circ} 05.283^{\prime} \mathrm{E}, 18-25 \mathrm{Sept} 2002$, S van Noort, Malaise trap LW02-N8-M48, Sand Plain Fynbos (2 females) [SAMC]; Langberg Farm, (3 km $280^{\circ} \mathrm{W}$ Langebaanweg) $32^{\circ} 58.045^{\prime} \mathrm{S} 18^{\circ} 07.418^{\prime} \mathrm{E}, 18-25$ Sept 2002, S van Noort, Malaise trap LW02-N1-M35, Sand Plain Fynbos (1 male, 1 female) [CASC]; Anyskop Farm, (5.5 km 290 W Langebaanweg) 32 $57.394 ' \mathrm{~S}$ $18^{\circ} 05.324^{\prime} E$, 25.ix-2.x 2002, S van Noort, Malaise trap LW02-N7-M64, Sand Plain Fynbos SAM-HYMP0024414 (4 females, 2 males) [SAMC]; Anyskop Farm, (5.5 km 290 W Langebaanweg) 32 57.394'S $18^{\circ} 05.324^{\prime} \mathrm{E}, 9-16$ Oct 2002, S van Noort, Malaise trap LW02-N7-M98, Sand Plain Fynbos (2 females)

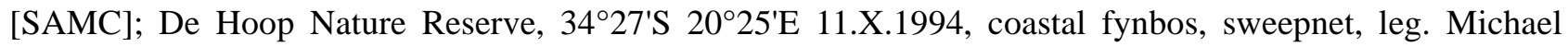
Söderlund (1 male) [ULMZ].

Image deposition. A MorphBank collection of images of $P$. rostratus can be accessed via http://morphbank.net/Show/?id=110332.

\section{Pycnostigmus mastersonae n. sp. Buffington \& van Noort}

(Fig. 3)

Description. FEMALE. Head. Metallic yellow/green luster over entire head (Figs 3A \& 3B), shagreened, weakly setose (Fig. 3E). Scape and radicle dark brown-black, flagellomeres orange, scape 1.2x length of radicle, 16 flagellomeres present, moniliform.

Mesosoma. Entire mesosoma with yellow/green luster. Lateral aspect of pronotum smooth, glabrous; anterior half of mesopleuron as well as area below mesopleural carina weakly striate; area under mesopleural triangle smooth; dorsal and ventral margins of mesopleural triangle clearly visible, center of triangle setose (Figs 3A \& 3B). Mesoscutum weakly shagreened anteriorly, becoming progressively smoother posteriorly; notaulices complete, originating at anterior end of parascutal impression; at convergence, notaulices parallel a narrow impression (Fig. 3C). Center of scutellar disk slightly rugulose, all sides distinctly crenulate, posterior margin rounded to slightly squared off (Fig. 3C).

Metapleural-propodeal complex. Dorsal portion of metapleuron covered in long setae; ventral section completely shiny, glabrous (Fig. 3B). Propodeum rugulose, evenly covered by long setae; section between propodeal carinae glabrous, crenulate (Fig. 3C). Nucha extended posteriorly, deeply striate (Fig. 3B).

Metasoma. Petiole striate with a few, long setae; obscured anteriorly by syntergum. Syntergum smooth and shiny; posterior portion lacking setae. Entire metasoma, in lateral view, about as long as deep.

Wings. Pseudostigma weakly pigmented (marginal cell visible) (Fig. 3D).

Legs. Coxae setose and metallic, remaining portion of legs orange, non-metallic, evenly setose entirely to claws (Figs 3A \& 3B).

MALE. As in female, except entire antenna (scape, radicle and flagellomeres) dark brown/black, 18 antennal flagellomeres present and femora dark brown/black, tibiae slightly lighter (to orange), tarsomeres orange-brown, length of metasoma 1.67x depth.

Diagnosis. Separated from all other species of Pycnostigmus by having head and mesosoma (including coxae) metallic green-gold.

Etymology. Jill Masterson was murdered by Auric Goldfinger in the Fleming (1959) based United Artists movie Goldfinger. Masterson supposedly died by dermal asphyxiation when she was completely covered in gold paint. Her name is used since this species of Pycnostigmus is the only known metallic cynipoid (Ronquist pers. comm.; Buffington pers. obsv.). 

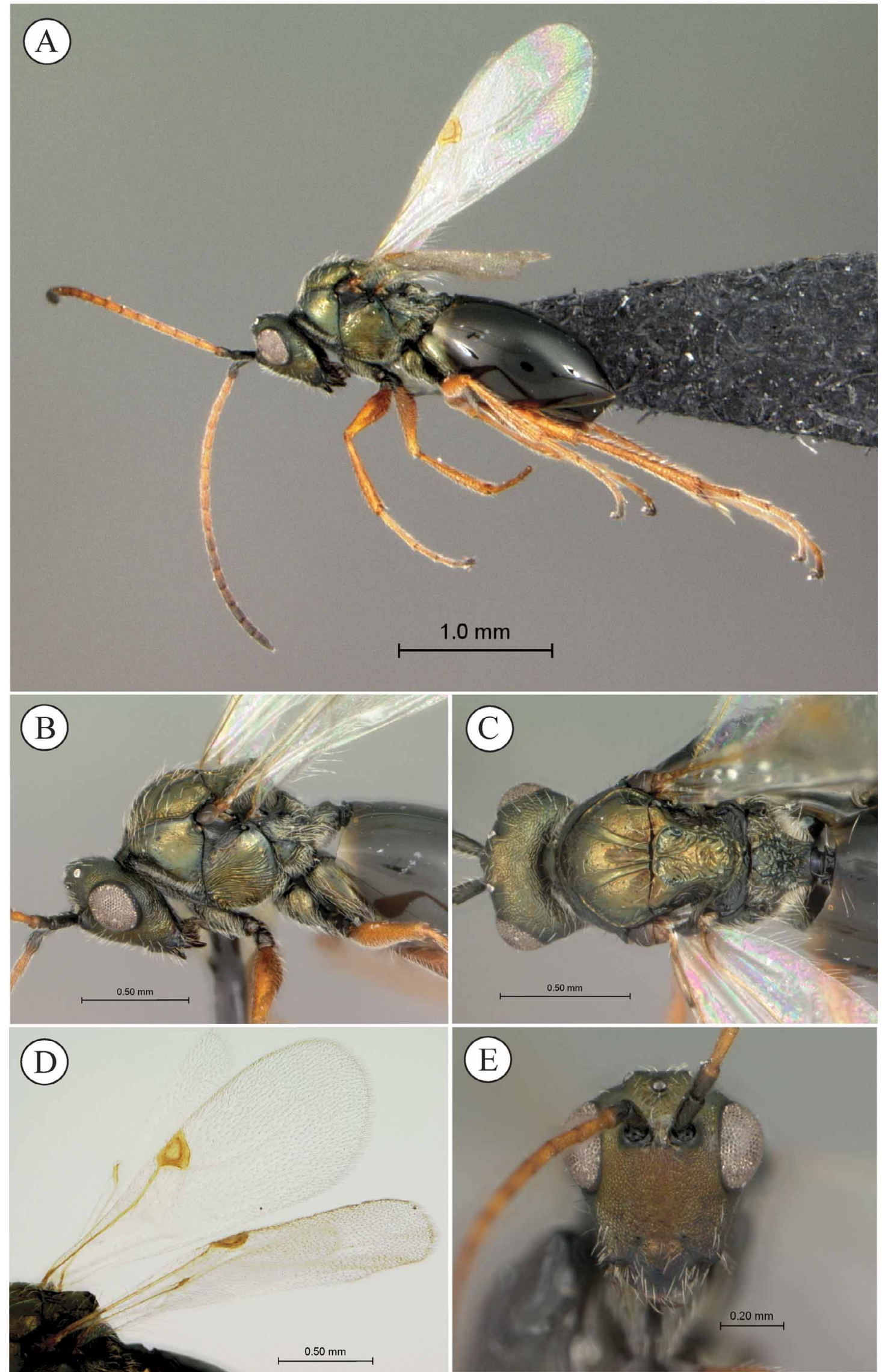

FIGURE 3. Pycnostigmus mastersonae Buffington \& van Noort, holotype specimen, female. A, habitus. B, head and mesosoma, lateral view. C, head and mesosoma, dorsal view. D, left forewing. E, head, anterior view. 
Distribution. South Africa: Western Cape (Fig. 13).

Material examined. Holotype: SOUTH AFRICA. Western Cape Province. [first label] Langberg Farm, (3 km 280 ${ }^{\circ} \mathrm{W}$ Langebaanweg) $32^{\circ} 58.045^{\prime} \mathrm{S} 18^{\circ} 07.418^{\prime} \mathrm{E}$, [second label] 4-11 Sept 2002, S van Noort, Malaise trap LW02-N1-M01, Sand Plain Fynbos. The holotype is a female mounted on a black card point. Deposited in SAMC.

Additional material. PARATYPES. SOUTH AFRICA. Western Cape Province. Koeberg Nature Reserve, 3337.622'S 18²4.259'E, 8 Aug-5 Sept 1997, S van Noort, Malaise trap KO97-M08, West Coast Strandveld (2 females, 17 males) [CASC, SAMC, ULMZ, USNM]; Koeberg Nature Reserve, 3337.622'S $18^{\circ} 24.259^{\prime} \mathrm{E}, 5$ Sept-3 Oct 1997, S van Noort, Malaise trap KO97-M09, West Coast Strandveld (2 females) [SAMC]; Koeberg Nature Reserve, 3337.622'S 18²4.259'E, 5 Sept-3 Oct 1997, S van Noort, Malaise trap KO97-M10, West Coast Strandveld (1 female); Koeberg Nature Reserve, 3337.622'S 18²4.259'E, 5 Sep-3 Oct 1997, S van Noort\& HG Robertson, Pitfall trap KO97-P47, West Coast Strandveld (1 female) [SAMC]; West Coast Fossil Park, (5.5 km 290 W Langebaanweg), 3257.402'S 1805.438'E, 4-11 Sept 2002, S van Noort, Malaise trap LW02-R5-M12, Rehabilitated mine dump (1female, 1 male) [SAMC]; West Coast Fossil Park, (5.5 km 270 ${ }^{\circ} \mathrm{W}$ Langebaanweg), 32 ${ }^{\circ} 58.117^{\prime} \mathrm{S} 18^{\circ} 05.789^{\prime} \mathrm{E}, 11-18 \mathrm{Sept} 2002$, S van Noort, Malaise trap LW02-U1-M27, Acacia cyclops on slimes dam (2 females) [SAMC]; Langberg Farm, (3 km 280 W Langebaanweg) $32^{\circ} 58.045^{\prime} \mathrm{S} 18^{\circ} 07.418^{\prime} \mathrm{E}, 18-25$ Sept 2002, S van Noort, Malaise trap LW02-N1-M35, Sand Plain Fynbos ( 3 females, 1 male) [1 male, 1 female in USNM; 2 females in CASC]; West Coast Fossil Park, (3 km $280^{\circ} \mathrm{W}$ Langebaanweg) $32^{\circ} 58.098^{\prime} \mathrm{S} 18^{\circ} 07.244^{\prime} \mathrm{E}$, 25.ix-2.x 2002, S van Noort, Malaise trap LW02-R2-M54, Rehabilitated mine dump (3 males) [SAMC]; Langberg Farm, (3 km 280 $\mathrm{W}$ Langebaanweg) 32 $58.045^{\prime} \mathrm{S}$ $18^{\circ} 07.418^{\prime} \mathrm{E}, 4-11$ Sept 2002, S van Noort, Malaise trap LW02-N1-M01, Sand Plain Fynbos (9 females and 7 males) [CASC, SAMC, ULMZ, USNM].

Image deposition. A MorphBank collection of images of $P$. mastersonae can be accessed via http://morphbank.net/Show/?id=110336.

\section{Pycnostigmus fossilensis n. sp. Buffington \& van Noort}

(Fig. 4)

Description. FEMALE. Head. Shiny with no sign of microsculpture around ocelli and on vertex (Figs 4B \& 4C); frons shagreened (Fig. 4E), cheeks smooth; setae present only on frons, around ocelli and occiput. Antenna entirely dark brown/black; scape $1.25 x$ length of radicle, short appressed setae on all flagellomeres, 12 flagellomeres present, basally moniliform and gradually becoming filiform towards apex.

Mesosoma. Lateral aspect of pronotum rugulose, shiny, sparsely covered in long setae (Fig. 4B). Mesopleuron smooth ventrad of mesopleural triangle and immediately dorsad of mesocoxa; reticulate striations present across remainder of mesopleuron, mesopleural carina indistinct; dorsal and ventral margins of mesopleural triangle clearly visible, setose (Fig. 4B). Mesoscutum entirely shiny (lacking microsculpture) with evenly scattered setae present over entire surface; notaulices complete, originating at anterior end of parascutal impression; area between posterior junction of notaulices delineated by teardrop-shaped impression (Fig. 4C). Disk of scutellum only smooth at center, remaining surface strongly rugulose; margin of disk well defined by raised, sharp carina (Fig. 4C).

Metapleural-propodeal complex. Metapleuron with long, thin setae on dorsal half, glabrous on ventral half (Fig. 4B). Propodeum crenulate, setation ranging from sparse to entirely glabrous; area between propodeal carinae weakly carinate, glabrous (Figs. 4B \& 4C). Nucha crenulate, not striate, protruding posteriorly (Fig. 4B).

Metasoma. Petiole striate with no visible setae; petiole not entirely obscured by anterior margin of syntergum. Syntergum smooth and shiny; posterior margin of syntergum, as well as T4, with a few long setae (Fig. 4A). Entire metasoma, in lateral view, about as long as deep. 

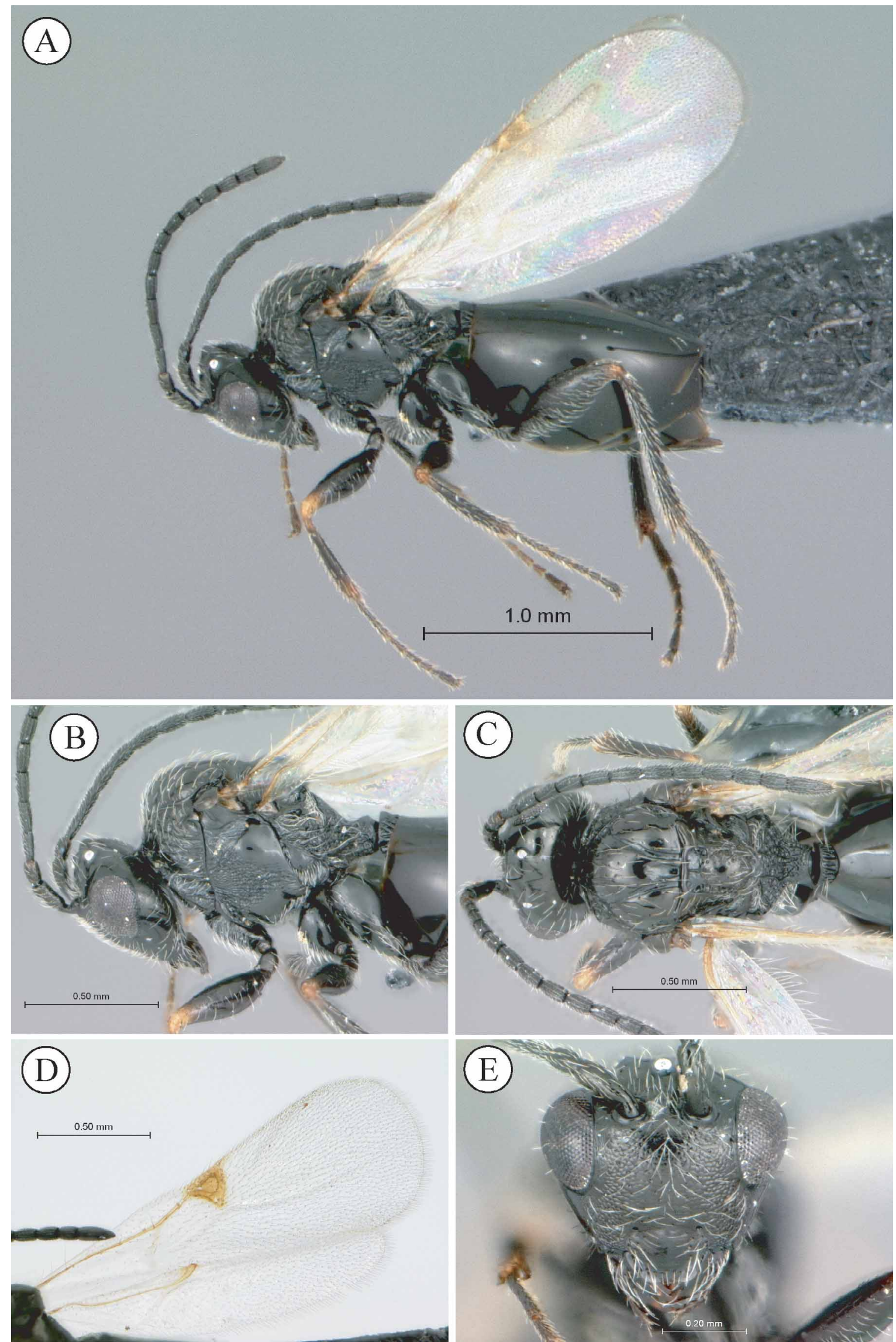

FIGURE 4. Pycnostigmus fossilensis Buffington \& van Noort, holotype specimen, female. A, habitus. B, head and mesosoma, lateral view. C, head and mesosoma, dorsal view. D, left forewing. E, head, anterior view. 
Wings. Pseudostigma weakly sclerotised such that the marginal cell is clearly visible (Fig. 4D).

Legs. Coxae and femora moderately setose, dark brown/black, non metallic; remaining portion of legs brown except for light brown, non metallic joints; legs evenly covered with long, non appressed setae entirely to claws (Fig. 4A).

MALE. As in female except: 15 antennal flagellomeres present; length of metasoma 1.67x depth.

Diagnosis. Separated from P. mastersonae by the head and mesosoma being non-metallic; from $P$. incognito and $P$. hoerikwaggoensis by having the disk of the scutellum smooth in center (weakly carinate in $P$. incognito, rugose in $P$. hoerikwaggoensis); from $P$. rostratus by having the mesopleuron almost entirely smooth (striate in $P$. rostratus) and the center of the disk of the scutellum smooth (entirely rugose in $P$. rostratus.)

Etymology. Named for the type locality, West Coast Fossil Park, a satellite of Iziko Museums of Cape Town. Phosphate mining operations uncovered a 5 million year old fossil site where bones of over 200 species, including bears and sabre-toothed cats, are preserved.

Distribution. South Africa: Western Cape (Fig. 13).

Material examined. Holotype: SOUTH AFRICA. Western Cape Province. [first label] West Coast Fossil Park, (4km 290 E Langebaanweg), 32 57.512'S 1806.728'E, [second label] 1-8 Sep 2004, S van Noort, Malaise trap LW02-R7-M318, rehabilitated mine dump. [third label] SAM-HYM P0024403. The holotype is a female mounted on a black card point. Deposited in SAMC.

Additional material. PARATYPES: SOUTH AFRICA. Western Cape Province. Koeberg Nature Reserve, 33³7.622'S 18²4.259'E, 8 Aug-5 Sept 1997, S van Noort, Malaise trap KO97-M07, West Coast Strandveld, SAM-HYM P0024710 (7 females, 6 males) [CASC, SAMC, ULMZ, USNM]; Koeberg Nature Reserve, 33³7.622'S 18²4.259'E, 8 Aug- Sep 1997, S van Noort \& HG Robertson, Pitfall trap KO97-P40, West Coast Strandveld, SAM-HYM P0024709 (1 female) [SAMC]; Langberg Farm, (3km 270 ${ }^{\circ}$ W Langebaanweg), 32 $58.461^{\prime} S$ 18 07.344'E, 25.viii-1.ix.2004, S van Noort, Malaise trap LW02-N2-M315, sand plain fynbos, SAM-HYM P0024404 (1 male) [SAMC]; West Coast Fossil Park, (5.5 km 290 ${ }^{\circ} \mathrm{W}$ Langebaanweg) $32^{\circ} 57.402^{\prime} \mathrm{S} 18^{\circ} 05.438^{\prime} \mathrm{E}, 4-11$ Sept 2002 , S van Noort, Malaise trap LW02-R5-M12, Rehabilitated mine dump, SAM-HYM P0024415 (1 male) [SAMC].

Image deposition. A MorphBank collection of images of $P$. fossilensis can be accessed via http://morphbank.net/Show/?id=110334.

\section{Pycnostigmus incognito n. sp. Buffington \& van Noort}

(Fig. 5)

Description. FEMALE. Head. Shiny without microsculpture around ocelli and on vertex (Fig. 5C); frons shagreened (Fig. 5E), cheeks weakly striate; setae only present on frons and occiput. Antenna entirely dark brown/black; scape 1.25x length of radicle, short appressed setae present on all 14 flagellomeres, filiform. Mesosoma. Lateral aspect of pronotum entirely smooth to weakly rugulose, shiny, with few sparse, long setae (Fig. 5B). Mesopleuron entirely smooth except for faint striations at anterior end of mesopleural carina; dorsal and ventral margins of mesopleural triangle clearly visible, setose (Fig. 5B). Mesoscutum entirely shiny (lacking microsculpture) with several scattered setae present over entire surface; notaulices complete, originating at anterior end of parascutal impression; area between posterior junction of notaulices delineated by teardropshaped impression (Fig. 5C). Disk of scutellum weakly carinate in center, remaining surface strongly rugulose; margin of disk well defined by raised, sharp carina (Fig. 5C).

Metapleural-propodeal complex. Metapleuron with longer, fine setae on dorsal half, glabrous on ventral half (Fig. 5B). Propodeum crenulate, varying from sparsely setose to entirely glabrous; area between propodeal carinae weakly carinate, glabrous (Figs 5B \& 5C). Nucha crenulate, not striate, protruding posteriorly (Fig. 5B). 

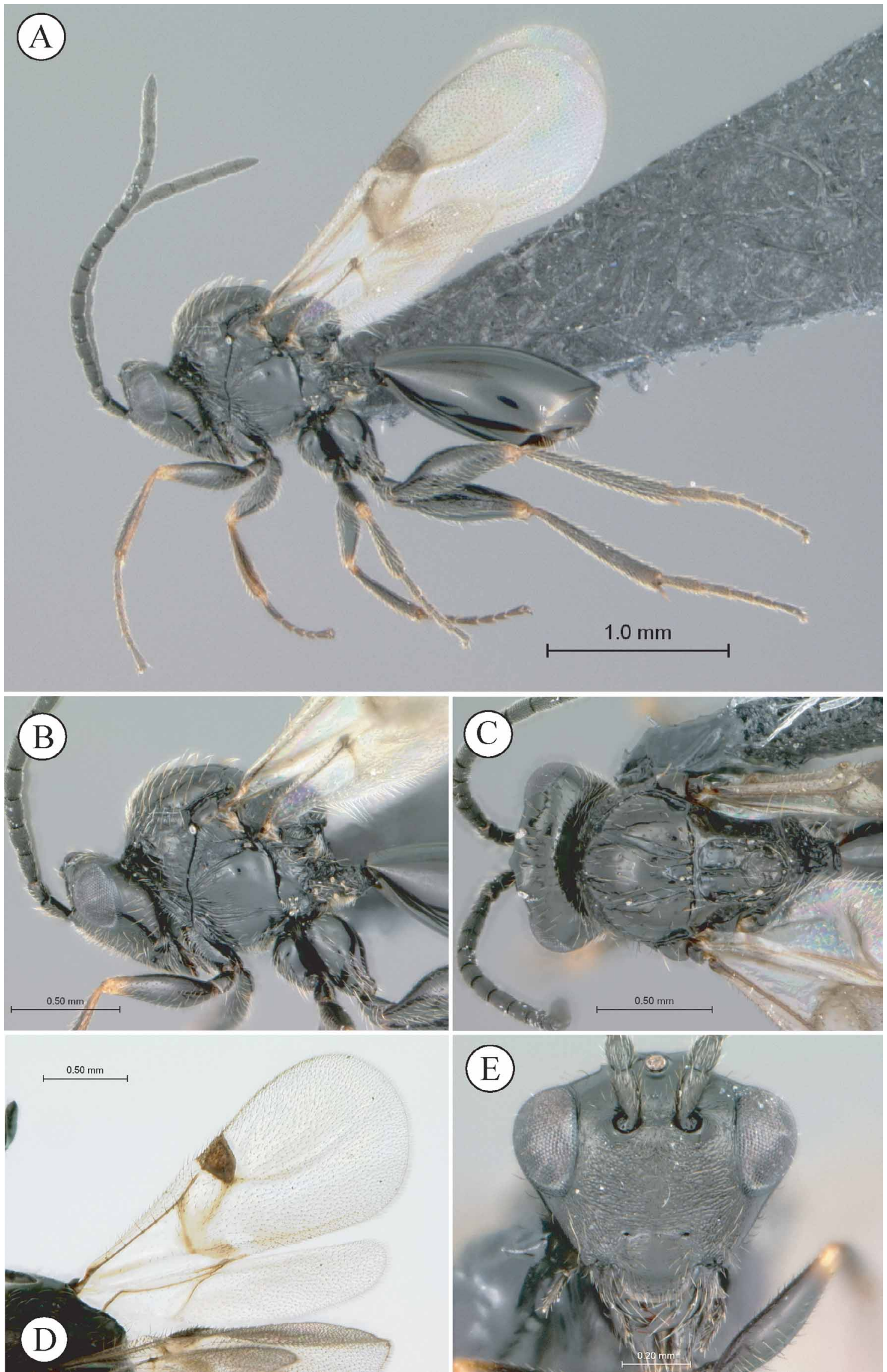

FIGURE 5. Pycnostigmus incognito Buffington \& van Noort, holotype specimen, female. A, habitus. B, head and mesosoma, lateral view. C, head and mesosoma, dorsal view. D, left forewing. E, head, anterior view. 
Metasoma. Petiole striate without visible setae; petiole obscured anteriorly by syntergum. Syntergum smooth and shiny; posterior margin of syntergum, as well as T4, with a few long setae (Fig. 5A). Entire metasoma, in lateral view, about as long as deep.

Wings. Pseudostigma strongly sclerotised, marginal cell faintly visible (Fig. 5D).

Legs. Coxae and femora setose, dark brown/black, non metallic; remaining portion of legs brown except for orange, non metallic joints; legs evenly covered with long, non appressed setae entirely to claws (Fig. 5A).

MALE. As in female except: 15 antennal flagellomeres present; metasoma two-thirds longer than deep.

Diagnosis. Separated from $P$. mastersonae by the head and mesosoma being non-metallic; from $P$. fossilensis by having the disk of the scutellum weakly carinate (center smooth in P. fossilensis) and from P. rostratus and P. hoerikwaggoensis by having the mesopleuron almost entirely smooth (striate in P. rostratus and P. hoerikwaggoensis).

Etymology. Name refers to the mask-like shagreened surface sculpturing on frons and clypeal region.

Distribution. South Africa: Western Cape (Fig. 13).

Material examined. Holotype: SOUTH AFRICA. Western Cape Province. [first label] Langberg Farm, ( $3 \mathrm{~km} 270^{\circ} \mathrm{W}$ Langebaanweg), 32 58.461'S 1807.344'E, [second label] 1-8 Sep 2004, S van Noort, Malaisetrap LW02-N2-M317, sand plain fynbos, [third label] SAM-HYM P0024400. The holotype is a male mounted on a black card point. Deposited in SAMC.

Additional material. PARATYPES: SOUTH AFRICA. Western Cape Province. Koeberg Nature Reserve, 33³7.622'S 18²4.259'E, 8 Aug-5 Sept 1997, S van Noort, Malaise trap KO97-M08, West Coast Strandveld, SAM-HYM P0024714 (1 male) [SAMC]; Koeberg Nature Reserve, 33³7.622'S 18²4.259'E, 5 Sept-3 Oct 1997, S van Noort, Malaise trap KO97-M09, West Coast Strandveld, SAM-HYM P0024715 (2 females) [SAMC, USNM]; Koeberg Nature Reserve, 3337.622'S 18²4.259'E, 5 Sept-3 Oct 1997, S van Noort, Malaise trap KO97-M10, West Coast Strandveld, SAM-HYM P0024716 (2 females, 2 males) [SAMC, ULMZ]; Langberg Farm, (3km 270 ${ }^{\circ} \mathrm{W}$ Langebaanweg), 32 58.461 'S 18 07.344'E, 1-8 Sep 2004, S van Noort, Malaise trap LW02-N2-M317, sand plain fynbos, SAM-HYM P0024400 (1 male) [SAMC]; Koeberg Nature Reserve, 33'37.52'S 18²5.33'E, 8 August 1997, S. van Noort, sweep 1, Metalasia muricata and Restio sp., Sand plain fynbos, SAM-HYM P0024395 (1 male) [SAMC]; West Coast Fossil Park, $\left(4 \mathrm{~km} 270^{\circ} \mathrm{W}\right.$ Langebaanweg) $32^{\circ} 58.483^{\prime} \mathrm{S} 18^{\circ} 06.884^{\prime} \mathrm{E}, 11-18$ Sept 2002, S van Noort, Malaise trap LW02-N5-M24, Fynbos on Limestone, SAM-HYM P0024416 (2 males) [SAMC].

Image deposition. A MorphBank collection of images of $P$. incognito can be accessed via http://morphbank.net/Show/?id=110335.

\section{Pycnostigmus hoerikwaggoensis n. sp. Buffington \& van Noort}

(Fig. 6)

Description. FEMALE. Head. Shiny without microsculpture around ocelli and on vertex (Fig. 6C); frons shagreened (Fig. 6E), cheeks weakly striate; setae present only on frons and occiput. Antenna entirely dark brown/black; scape 1.25x length of radicle, short appressed setae present on all 13 flagellomeres, filiform.

Mesosoma. Lateral aspect of pronotum stongly rugulose, shiny, with few sparse, long setae (Fig. 6B). Mesopleuron with numerous strigae above and below mesopleural carina; dorsal and ventral margins of mesopleural triangle clearly visible, setose (Fig. 6B). Mesoscutum entirely shiny (lacking microsculpture) with several scattered setae present over entire surface; notaulices complete, originating at anterior end of parascutal impression; area between posterior junction of notaulices delineated by teardrop-shaped impression (Fig. 6C). Disk of scutellum strongly rugulose posteriorly; margin of disk well defined by raised, sharp carina (Fig. 6C). 


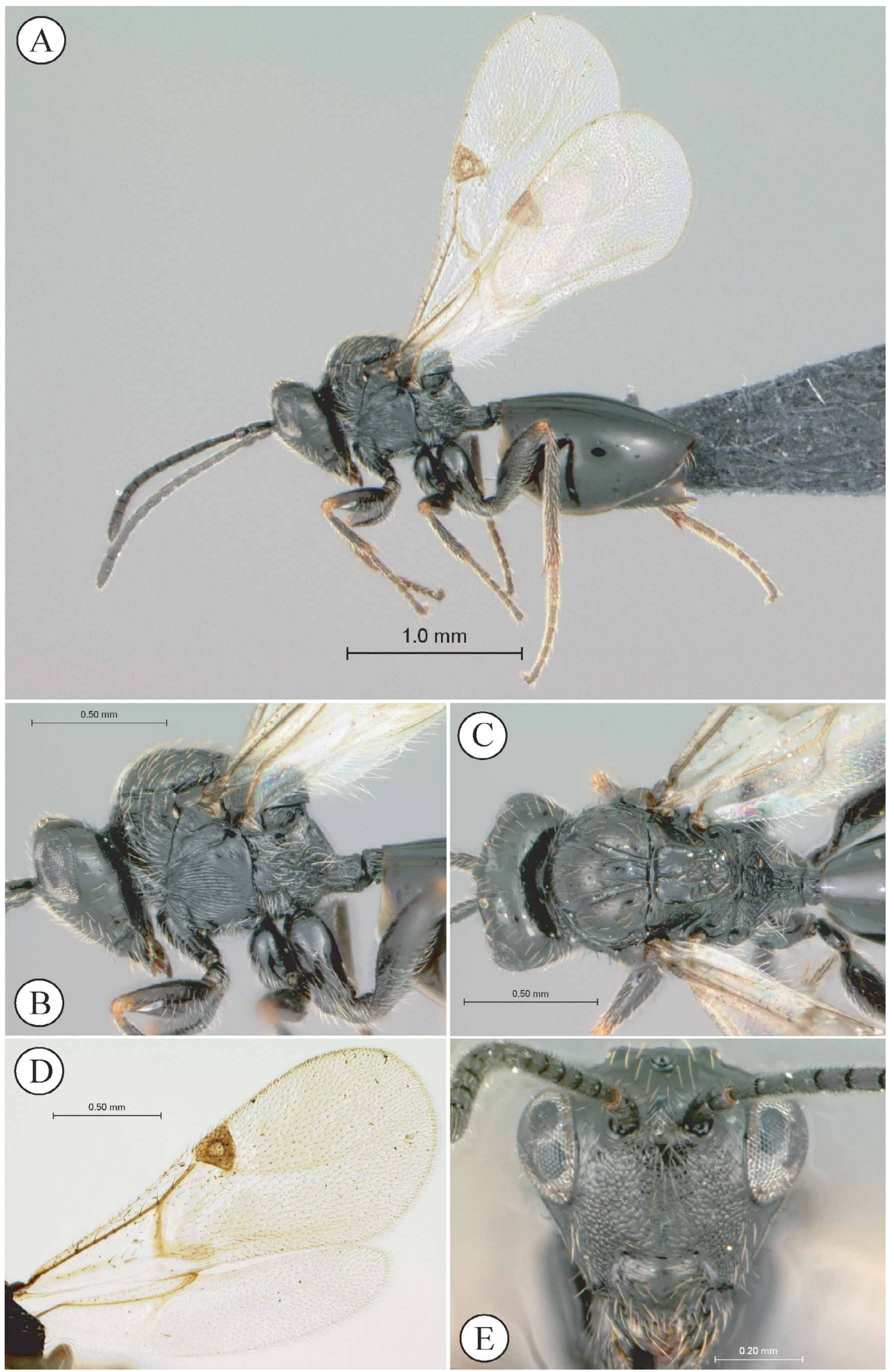

FIGURE 6. Pycnostigmus hoerikwaggoensis Buffington \& van Noort, holotype specimen, female. A, habitus. B, head and mesosoma, lateral view. C, head and mesosoma, dorsal view. D, left forewing. E, head, anterior view. 
Metapleural-propodeal complex. Metapleuron with long, thin setae on dorsal half, glabrous on ventral half (Fig. 6B). Propodeum crenulate, sparsely setose to entirely glabrous; area between propodeal carinae weakly carinate, glabrous (Figs 6B \& 6C). Nucha crenulate, not striate, protruding posteriorly (Fig. 6B).

Metasoma. Petiole striate without setae; petiole obscured anteriorly by syntergum (Fig. 6B). Syntergum smooth and shiny; posterior margin of syntergum, as well as T4, with a few long setae (Fig. 6A). Entire metasoma, in lateral view, about as long as deep.

Wings. Pseudostigma weakly sclerotised such that marginal cell is visible (Fig. 6D).

Legs. Coxae and femora setose, dark brown/black, non metallic; remaining portion of legs brown except for orange, non metallic joints; legs evenly covered with long, non appressed setae entirely to claws (Fig. 6A).

MALE: Unknown.

Diagnosis. Separated from P. mastersonae by the head and the mesosoma being non-metallic, from P. fossilensis by having the disk of the scutellum rugose (center smooth in P. fossilensis), from $P$. rostratus by lacking the deep fovea on the lateral aspects of the pronotum (foveolate in P. rostratus) and from $P$. incognito by having numerous strigae on the mesopleuron (few to no strigae in P. incognito).

Etymology. Named in honor of the Table Mountain National Park. The original inhabitants of the Cape, the Khoi Khoi, called Table Mountain Hoerikwaggo-"sea mountain" or "mountain in the sea". The type locality, Constantiaberg, now forms part of Table Mountain National Park.

Distribution. South Africa: Western Cape (Fig. 13).

Material examined: Holotype: SOUTH AFRICA. Western Cape Province. [first label] Cape Town, Constantiaberg, 520m, near road to mast, 340.' ${ }^{\prime} 1^{\circ} 23.5^{\prime} \mathrm{E}$, [second label] 10 October 1995, S van Noort, Mesic Mountain Fynbos, sweep [third label] SAM-HYM P0024707. The holotype is a female mounted on a black card point. The holotype is in good condition. Deposited in SAMC.

Additional material. PARATYPES: SOUTH AFRICA. Western Cape Province. Cape Town, Tokai State Forest, Constantiaberge, above Donkerboskloof, 460m, 3402'S 18²3.5'E, 5-12 Sept 1993, S van Noort, Mesic Mountain Fynbos on Sandstone, top kloof with forest elements, Malaise trap, SAM-HYM P005138 (1

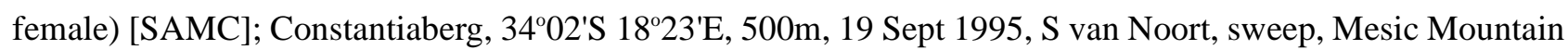
Fynbos, SAM-HYM P0024708 (1 female) [USNM]; NON-TYPE: Hottentot-Holland Mountains, Caledon C.C., Barnard 1916, SAM-HYM P002867 (1 female) [SAMC].

Image deposition. A MorphBank collection of images of $P$. hoerikwaggoensis can be accessed via http:// morphbank.net/Show/?id=110333.

\section{Tylosema Kieffer}

(Figs 7-9)

\section{Tylosema nigerrimum Kieffer}

(Fig. 7)

Tylosema nigerrimum Kieffer 1905:112. Type species by monotypy.

Redescription. holotype MALE: Head. Shagreened on vertex, cheeks (Fig. 7B) frons and occiput (Fig. 7E); sparse setae present on frons, occiput, genal area and area around ocelli. Antenna entirely dark brown/black; scape $1.7 x$ length of radicle, short appressed setae present on all 13 flagellomeres, moniliform.

Mesosoma. Lateral aspect of pronotum strongly areolate, rugose, with few sparse setae (Fig. 7B). Mesopleuron entirely rugulose/areolate dorsal of mesopleural carina; gently shagreened below mesopleural carina (Fig. 7B); dorsal and ventral margins of mesopleural triangle clearly visible, setose, with distinct grooves following contours of anterior margin of mesopleural triangle (Fig. 7B). Mesoscutum shagreened 
(A)
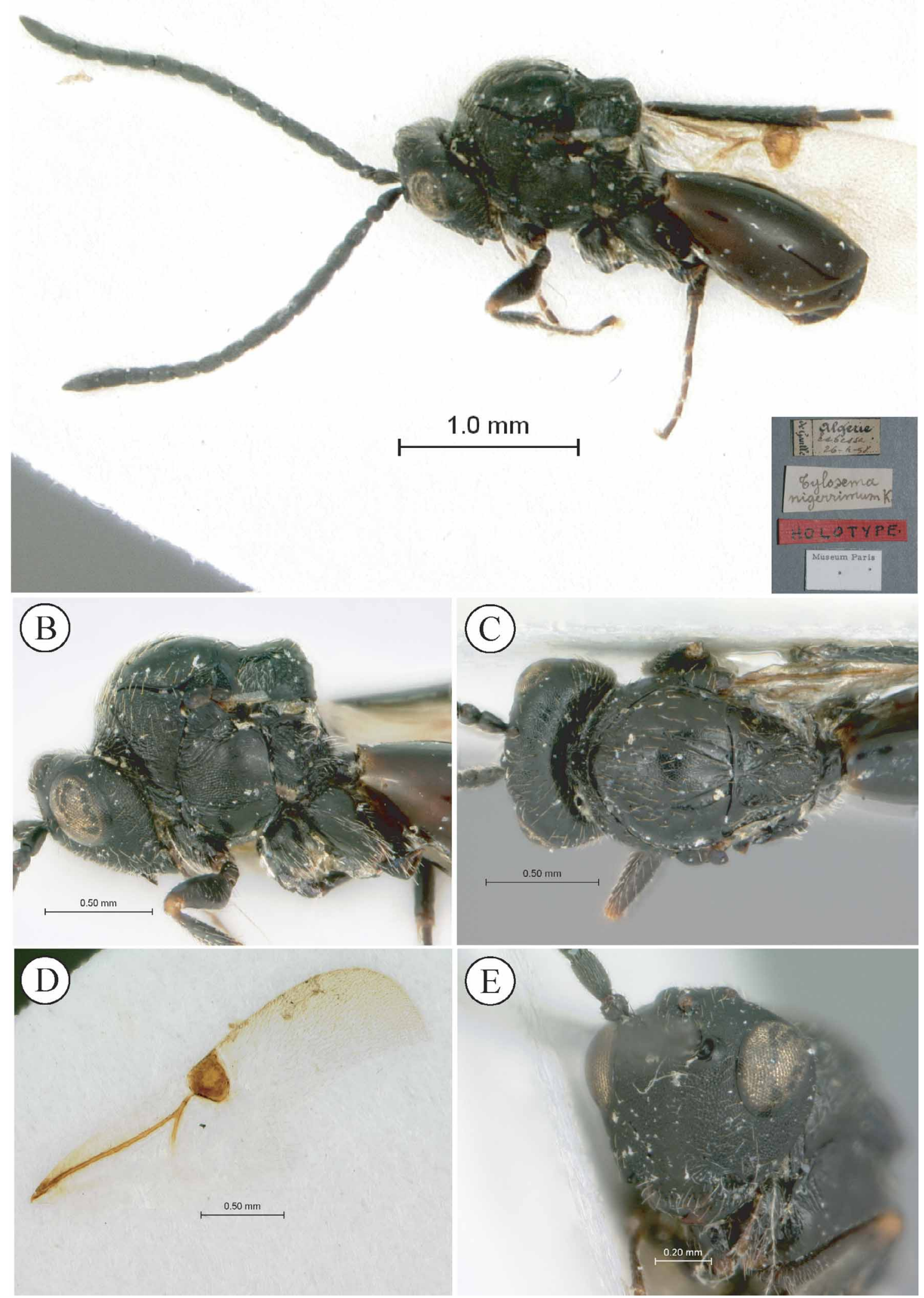

FIGURE 7. Tylosema nigerrimum Kieffer, holotype specimen, male. A, habitus. B, head and mesosoma, lateral view. C, head and mesosoma, dorsal view. D, left forewing. E, head, anterior view. 
with moderate setation present; notaulices incomplete anteriorly, parascutal impression obsolete; area between posterior junction of notaulices delineated by a 'pinched' area (Fig. 7C). Disk of scutellum shagreened and evenly rounded; margin of disk well defined by a distinct carina (Fig. 7C).

Metapleural-propodeal complex. Metapleuron with a few scattered setae along posterior margins (Fig. 7B). Propodeum crenulate with few long setae; area between propodeal carinae weakly carinate, glabrous. Nucha crenulate, not striate, slightly protruding posteriorly (Fig. 7B).

Metasoma. Petiole obscured anteriorly by syntergum. Syntergum smooth and shiny; posterior portion lacking setae. Entire metasoma, in lateral view, 1.67x longer than deep.

Wings. Pseudostigma weakly sclerotised such that the marginal cell is visible (Fig. 7D).

Legs. Coxae and femora setose, dark brown/black; rest of legs brown except for pale brown joints; evenly setose entirely to claws (Figs 7A and B).

FEMALE. Unknown.

Diagnosis. Separated from $T$. dayae by having the scutellar disk shagreened and distinctly margined posteriorly (smooth and lacking margin in $T$. dayae) and from $T$. ronquisti by having a rugulose/areolate lateral aspect of the pronotum (smooth in T. ronquisti) and a shagreened mesoscutum (smooth in T. ronquisti).

Distribution. Northern Africa: Algeria (Fig. 12).

Material examined. Holotype: NORTHERN AFRICA: [first label] Algeria, Tebessa, 26-4-(18)98, deGaulle, [second label] Tylosema nigerrimum K (handwriting unknown), [third label] HOLOTYPE, [fourth label] Museum Paris [see inset Fig. 7A for labels]. The type is a male, in good condition (c.f. Fig. 7A), having been remounted on a white card; the left hind leg and forewing have been mounted separately from the body. Deposited in MNHN.

Additional material. None.

Image deposition. A MorphBank collection of images of T. nigerrimum can be accessed via http://morphbank.net/Show/?id=110341.

\section{Tylosema dayae n. sp. Buffington \& van Noort}

(Fig. 8)

Description. FEMALE. Head. Shiny on vertex and cheeks (Fig. 8C), weakly shagreened on frons and occiput (Fig. 8E); setae present only on frons and occiput, area around ocelli glabrous. Antenna entirely dark brown/ black; scape 1.8x length of radicle, short appressed setae present on all 10 flagellomeres, moniliform. Mesosoma. Lateral aspect of pronotum entirely smooth, shiny, glabrous (Fig. 8B). Mesopleuron entirely smooth except for small area below mesopleural carina; dorsal and ventral margins of mesopleural triangle clearly visible, setose (Fig. 8B). Mesoscutum entirely shiny (lacking microsculpture) with few scattered setae present anteriorly between notaulices; notaulices incomplete anteriorly, parascutal impression obsolete; area between posterior junction of notaulices delineated by narrow impression (Fig. 8C). Disk of scutellum entirely smooth and evenly rounded, margin not defined, gently sloping ventrally (Fig. 8C).

Metapleural-propodeal complex. Metapleuron setose along posterior margins (Fig. 8B). Propodeum crenulate, evenly covered by moderately long setae; area between propodeal carinae weakly carinate, glabrous. Nucha crenulate, not striate, slightly protruding posteriorly (Fig. 8C).

Metasoma. Petiole striate with a few, long setae; obscured anteriorly by syntergum. Syntergum smooth and shiny; posterior portion lacking setae (Fig. 8A). Entire metasoma, in lateral view, about as long as deep.

Wings. Pseudostigma strongly sclerotised, no marginal cell visible (Fig. 8D).

Legs. Coxae and femora setose, dark brown/black; rest of legs orange, evenly setose entirely to claws (Fig. 8A).

MALE. As in female except: 16 flagellomeres present; metasoma two-thirds longer than deep. 

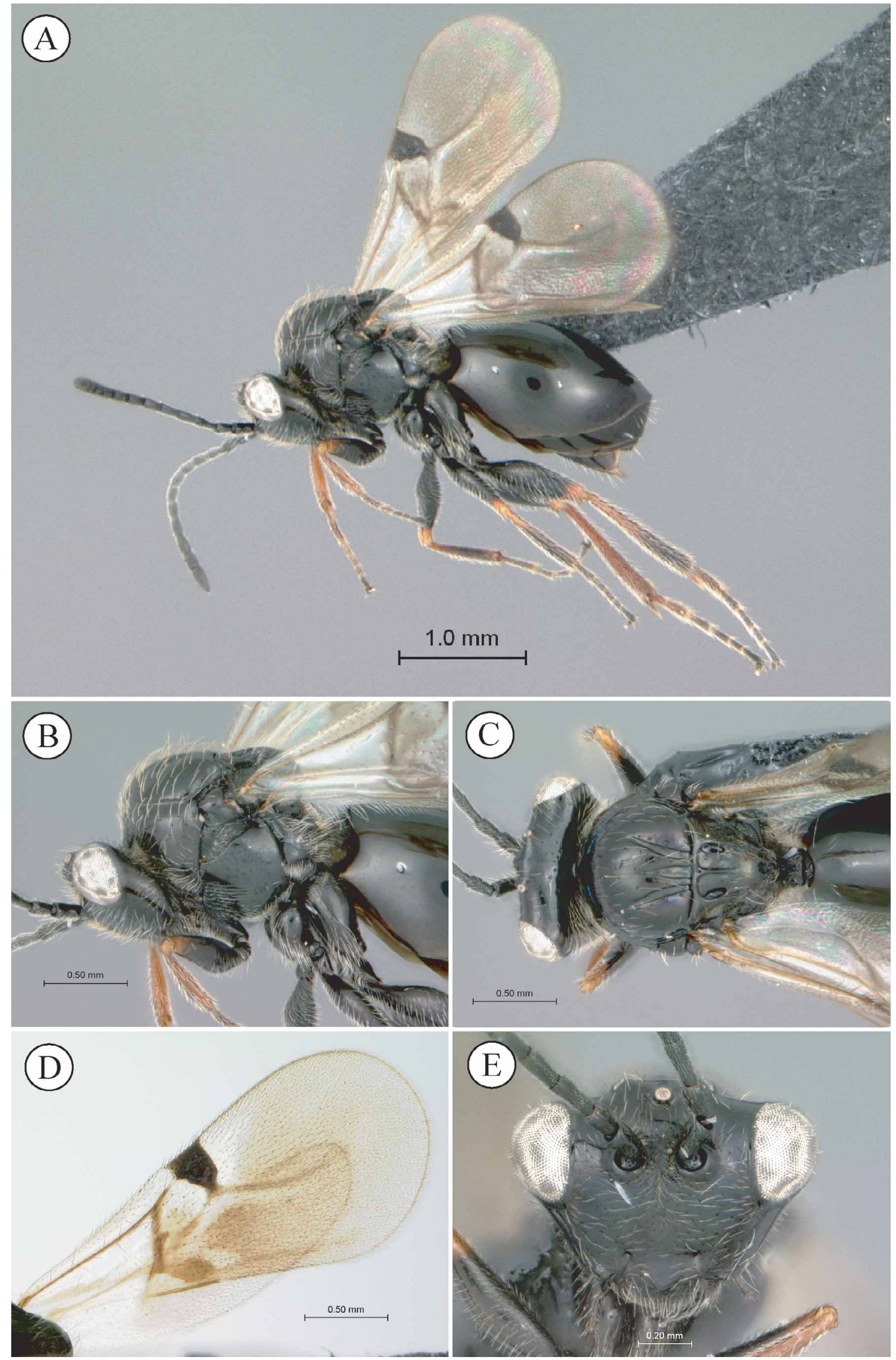

FIGURE 8. Tylosema dayae Buffington \& van Noort, paratype specimen, female. A, habitus. B, head and mesosoma, lateral view. C, head and mesosoma, dorsal view. D, left forewing. E, head, anterior view. 
Diagnosis. Separated from T. ronquisti and T. nigerrimum by having an entirely smooth scutellar disk (rugulose and/or shagreened around lateral and posterior margins in T. ronquisti and T. nigerrimum) and lacking a distinct posterior margin (bounded by distinct carina in T. ronquisti and T. nigerrimum).

Etymology. Named in honor of Jennifer Day, University of Cape Town, Cape Town, South Africa.

Distribution. South Africa: Western Cape, Northern Cape (Fig. 13).

Material examined. Holotype: SOUTH AFRICA. Northern Cape Province. [first label] Kamieskroon, Namaqualand [upland succulent karoo], [second label] Museum staff [South Africa Museum], 1930. The type is a male, in good condition, having been remounted on a card by M. Sporrong (Sweden). Deposited in SAMC.

Additional material. PARATYPES: SOUTH AFRICA. Western Cape Province. West Coast Fossil Park, (4 km 270 ${ }^{\circ} \mathrm{W}$ Langebaanweg) $32^{\circ} 58.444 ' \mathrm{~S} 18^{\circ} 06.731 ' \mathrm{E}, 25 . \mathrm{ix}-2 . \mathrm{x}$ 2002, S van Noort, Malaise trap LW02N6-M59, Sand Plain Fynbos dominated by Lebeckia (1 female) [SAMC]; Anyskop Farm, (4 km 270 W Langebaanweg) $32^{\circ} 58.611$ 'S $18^{\circ} 06.976 ' E$, 11-18 Sept 2002, S van Noort, Malaise trap LW02-N4-M23, Fynbos on Limestone ( 1 female, 1 male) [SAMC]; West Coast Fossil Park, (4 km 280 E Langebaanweg) $32^{\circ} 57.817^{\prime} \mathrm{S} 18^{\circ} 06.837^{\prime} \mathrm{E}, 11-18$ Sept 2002, S van Noort, Malaise trap LW02-R8-M34, Rehabilitated mine dump (1 male) [SAMC]; Anyskop Farm, (4 km 270 $\mathrm{W}$ Langebaanweg) 32 $58.611^{\prime} \mathrm{S} 18^{\circ} 06.976^{\prime} \mathrm{E}, 18-25$ Sept 2002, S van Noort, Malaise trap LW02-N4-M40, Fynbos on Limestone (2 females) [CASC]; West Coast Fossil Park, (4 km 270 ${ }^{\circ} \mathrm{W}$ Langebaanweg) 32 $58.483^{\prime} \mathrm{S} 18^{\circ} 06.884^{\prime} \mathrm{E}, 18-25$ Sept 2002, S van Noort, Malaise trap LW02-N5-M41, Fynbos on Limestone (1 female, 1 male) [USNM]; West Coast Fossil Park, (4 km 270 W Langebaanweg) $32^{\circ} 58.444 ' S 18^{\circ} 06.731^{\prime} E, 2-9$ Oct 2002, S van Noort, Malaise trap LW02-N6-M76, Sand Plain Fynbos dominated by Lebeckia (2 females) [SAMC]; Walker Bay Nature Reserve, 34²7.414'S 19²1.393'E, 9 Aug-6 Sept 1997, S van Noort, Malaise trap WB97-M08, South Coast Strandveld, 57 m altitude (10 females; 5 males); De Hoop Nature Reserve, $34^{\circ} 27^{\prime} \mathrm{S} 20^{\circ} 25^{\prime} \mathrm{E} 10 . X .1994$, on Mesembryanthemaceae in field surrounded by fynbos, sweepnet, leg. Michael Söderlund (1 female) [ULMZ]; $10 \mathrm{~km} \mathrm{~S}$ of Citrusdal, Koornlandskloof, S32 $40^{\prime}$ E19 02', 7-9.X.1994, at stand of Herrea blanda (Mesembryanthemaceae) on meadow at riverside, Malaise trap, leg. Michael Söderlund (1 female) [ULMZ]; N of Citrusdal, $1 \mathrm{~km} \mathrm{~N}$ of Hexrivier at Olifantsrivier, S32 $26^{\prime} \mathrm{E} 18^{\circ} 58^{\prime}, 6 . \mathrm{X} .1994$, indigenous and introduced shrubs at riverside, sweepnet, leg. Michael Söderlund (5 females) [ULMZ]; $10 \mathrm{~km} \mathrm{~S}$ of Citrusdal, Koornlandskloof, S32 ${ }^{\circ} 40^{\prime}$ E19 $02^{\prime}$, 5.X.1994, meadow at riverside, sweepnet, leg. Michael Söderlund (1 female) [ULMZ]; $10 \mathrm{~km} \mathrm{~S}$ of Cistrusdal, Koornlandskloof, S32 40' E1902', 8.X.1994, 17:30-19:00, in flowers of Herrea blanda (Mesembryanthemaceae) on meadow at riverside, leg. Michael Söderlund (3 females) [ULMZ]; $10 \mathrm{~km} \mathrm{~S}$ of Cistrusdal, Koornlandskloof, S32 40' E1902', 7.X.1994, meadow at riverside, sweepnet, leg. Michael Söderlund (7 females) [ULMZ].

Image deposition. A MorphBank collection of images of $T$. dayae can be accessed via http://morphbank.net/Show/?id=110342. The SEM's of this image series were created in conjunction with Fontal-Cazalla et al. (2002) because the pycnostigmines were considered an important outgroup taxon for inferring eucoiline (Figitidae) relationships. This taxon was referred to as 'Pycnostigmus sp.' in Fontal-Cazalla et al. (2002).

\section{Tylosema ronquisti Buffington \& van Noort}

(Fig. 9)

Description. FEMALE. Head. Shiny on vertex and cheeks (Fig. 9C), shagreened on frons and occiput (Fig. 9E); setae only present on frons and occiput, area around ocelli glabrous. Antenna entirely dark brown/black, scape 1.8x length of radicle, short appressed setae present on all flagellomeres, 10 flagellomeres present, moniliform. 

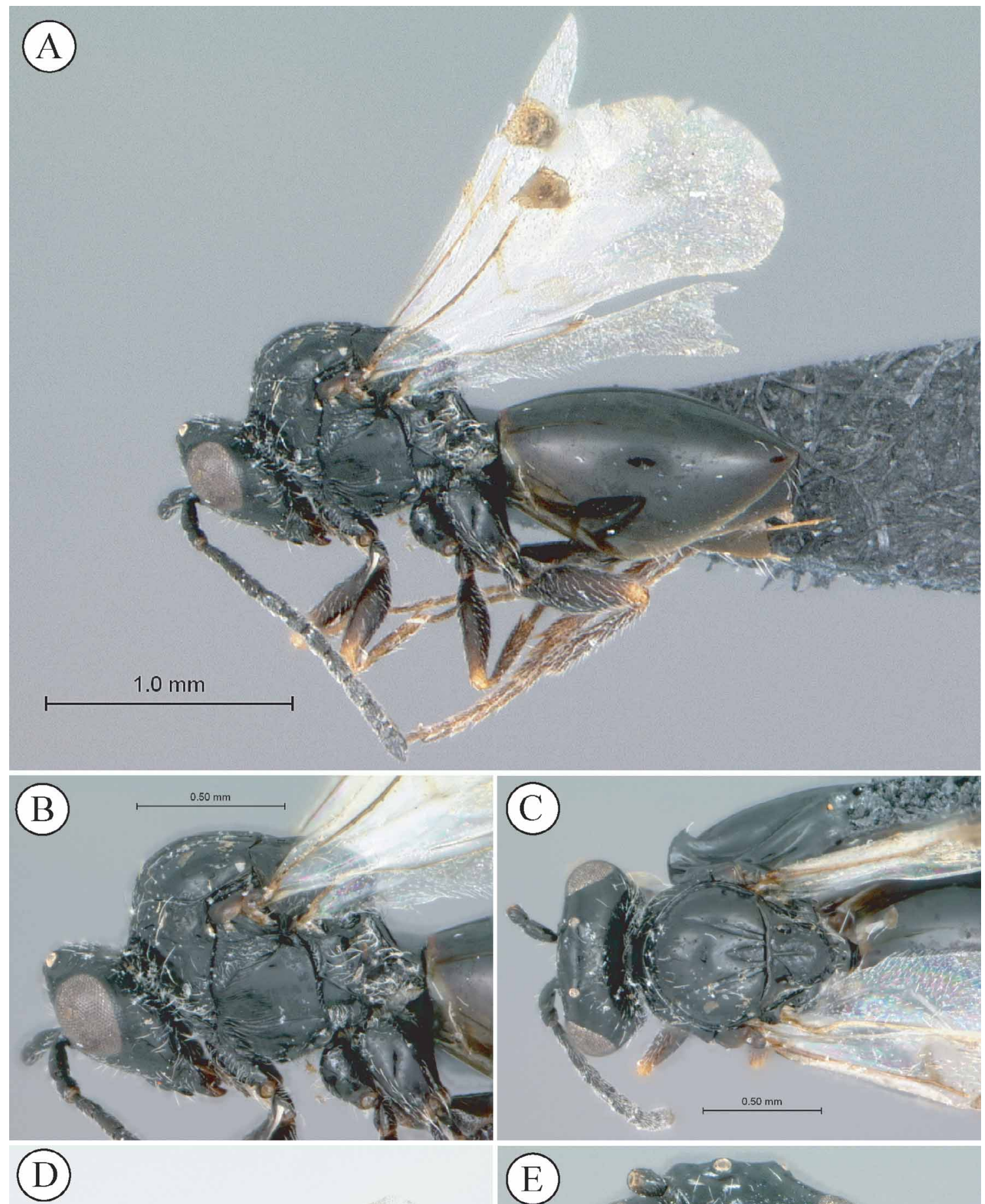

(E)
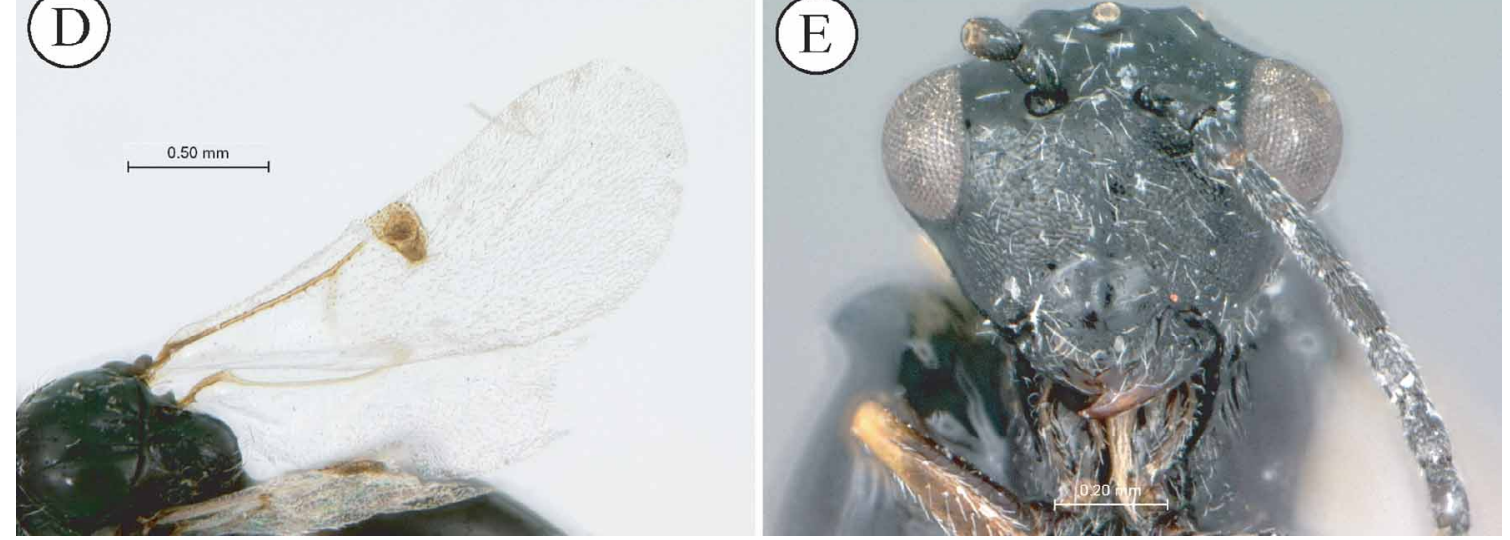

FIGURE 9. Tylosema ronquisti Buffington \& van Noort, holotype specimen, female. A, habitus. B, head and mesosoma, lateral view. C, head and mesosoma, dorsal view. D, left forewing. E, head, anterior view. 
Mesosoma. Lateral aspect of pronotum entirely smooth, shiny, glabrous (Fig. 9B). Mesopleuron entirely smooth; mesopleural carina comprised of a series of striations (not a single distinct carina); dorsal and ventral margins of mesopleural triangle clearly visible, setose (Fig. 9B). Mesoscutum entirely shiny (lacking microsculpture) with few scattered setae present anteriorly between notaulices; notaulices incomplete anteriorly, parascutal impression obsolete; area between posterior junction of notaulices delineated by narrow impression (Fig. 9C). Disk of scutellum smooth in center, gradually becoming more punctate and rugose around periphery; margin of disk with well-defined carina; disk gradually sloping ventrally (Fig. 9C).

Metapleural-propodeal complex. Dorsal half of metapleuron with few long setae, ventral half glabrous (Fig. 9B). Propodeum crenulate, sparsely covered by moderately long setae; area between propodeal carinae glabrous, smooth and shiny. Nucha smooth dorsally, slightly crenulate laterally, slightly protruding posteriorly.

Metasoma. Petiole striate no setae visible; obscured anteriorly by syntergum. Syntergum smooth and shiny; posterior portion lacking setae (Fig. 9A). Entire metasoma, in lateral view, about as long as deep.

Wings. Pseudostigma strongly sclerotised such that no marginal cell is visible (Fig. 9D).

Legs. Coxae and femora setose, dark brown/black; remaining portion of legs orange, evenly setose entirely to claws (Fig. 9A).

MALE. Unknown.

Diagnosis. Separated from $T$. dayae by having rugulose sculpture around lateral and posterior margins (entirely smooth in T. dayae) and the disk of the scutellum possessing a distinct posterior margin bounded by a carina (no carina in $T$. dayae) and from T. nigerrimum by having a smoother lateral aspect of pronotum (areolate and rugulose in T. nigerrimum).

Etymology. Named in honor of Fredrik Ronquist (Florida State University, Tallahassee, FL, USA).

Distribution. South Africa, Western Cape (Fig. 13).

Material examined. Holotype: SOUTH AFRICA. Western Cape Province. [first label] Langberg Farm, (3km 270 ${ }^{\circ} \mathrm{W}$ Langebaanweg), 32 $58.461^{\prime} \mathrm{S} 1^{\circ} 07.344^{\prime} \mathrm{E}$, [second label] 22-30 Sep 2004, S van Noort, Malaise trap LW02-N2-M323, sand plain fynbos, [third label] SAM-HYM P0024401, [fourth label] holotype designation label. The holotype is a female mounted on a black card point. The holotype is in good condition. Deposited in SAMC.

Image deposition. A MorphBank collection of images of T. ronquisti can be accessed via http://morphbank.net/Show/?id=110339.

\section{Trjapitziniola Kovalev}

(Figs 10-11)

\section{Trjapitziniola popovi (Belezin)}

(Fig. 10)

Tylosema popovi Belizin, 1951:567

Trjapitziniola popovi (Kovalov 1995:140). Type species by original designation and monotypy.

Redescription. non-type MALE, Head. Shiny without microsculpture around ocelli and on vertex (Fig. 10C); frons shagreened (Fig. 10E), cheeks smooth; setae present only on frons and occiput. Antenna entirely dark brown/black; scape 1.25x length of radicle, short appressed setae present on all 16 flagellomeres, filiform. Mesosoma. Upper part of lateral aspect of pronotum entirely smooth to weakly shagreened, shiny, with few sparse, long setae (Fig. 10B); pronotal carina present, extending ventrally from anterior half of pronotal plate. Mesopleuron with distinct striations anteriorly, smooth posteriorly; dorsal and ventral margins of mesopleural triangle clearly visible, glabrous anteriorly, weakly setose towards midpit (Fig. 10B). Mesoscutum entirely 


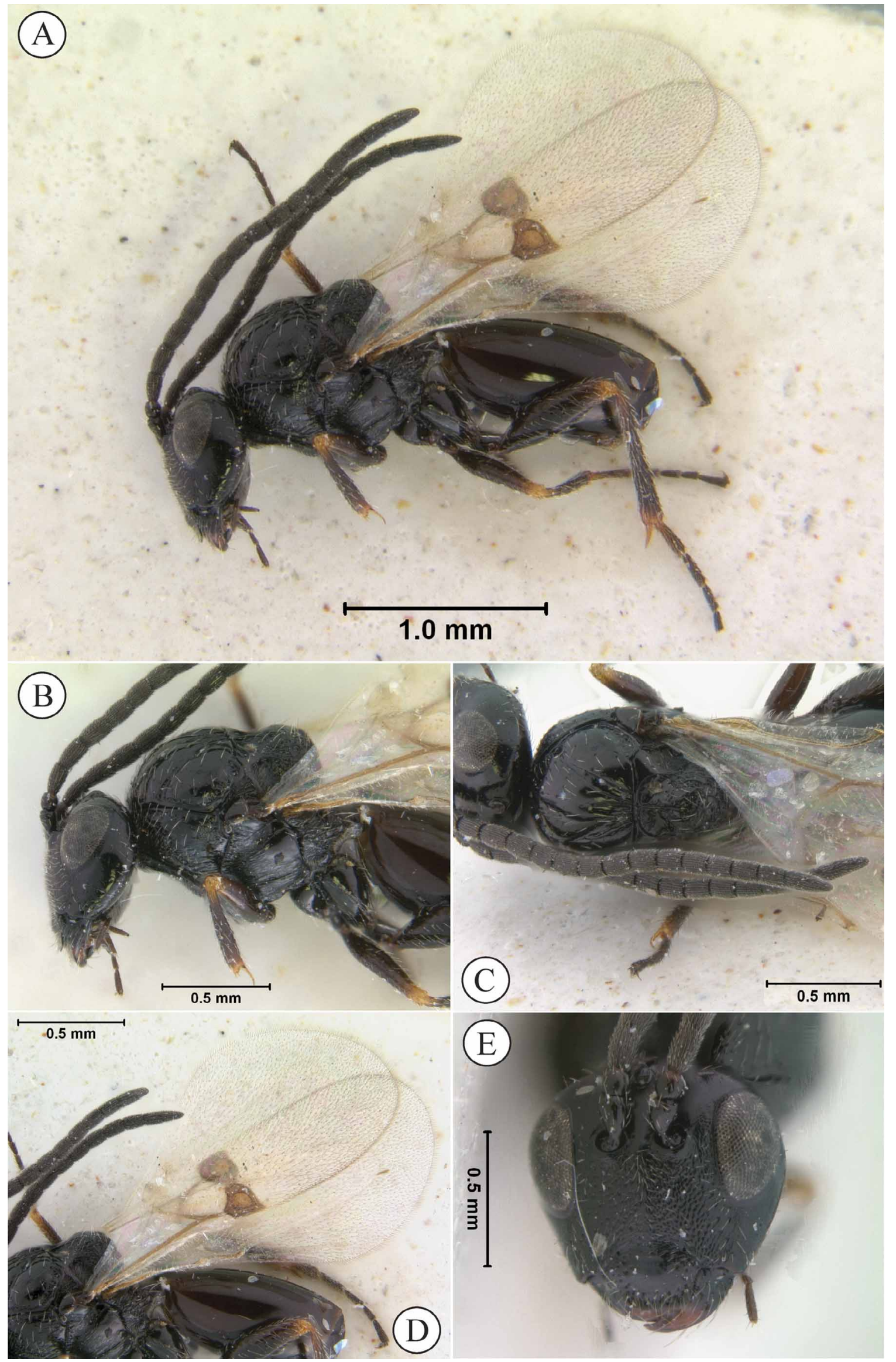

FIGURE 10. Trjapitziniola popovi (Belizin), non-type specimen, male. A, habitus. B, head and mesosoma, lateral view. $\mathrm{C}$, head and mesosoma, dorsal view. D, left forewing. E, head, anterior view. 
shiny (lacking microsculpture) with several scattered setae present over entire surface; notaulices complete, originating at anterior end of parascutal impression; area between posterior junction of notaulices delineated by elongate impression (Fig. 10C). Disk of scutellum anteriorly smooth, posteriorly strongly rugulose, distinctly angled midway, declined posteriorly; declined area flat (Figs 10B and 10D). Posterior margin of disk strongly rugose, bordered by raised carina.

Metapleural-propodeal complex. Metapleuron glabrous except for sparse setae within the antero-ventral cavity (Fig. 10B), strongly rugose, slightly smoother ventrally. Propodeum crenulate, sparsely setose to entirely glabrous; area between propodeal carinae strongly carinate, glabrous. Nucha crenulate, not striate, protruding posteriorly.

Metasoma. Petiole striate without visible setae; petiole obscured anteriorly by syntergum. Syntergum smooth and shiny, entirely glabrous (Fig. 10A). Entire metasoma, in lateral view, about as long as deep.

Wings. Pseudostigma weakly sclerotised, marginal cell clearly visible (Fig. 10D).

Legs. Coxae and femora setose, dark brown/black, non metallic; remaining portion of legs brown except for orange, non metallic joints; legs evenly covered with long, non appressed setae entirely to claws (Fig. 10A).

FEMALE. Data taken from Kovalev (1995). As in male except antenna 12 segmented, clavate; relative length of scape to radicle unpublished.

Diagnosis. Separated from $T$. vanharteni by having the scape $1.25 \mathrm{x}$ length of radicle (2x length of radicle in $T$. vanharteni), the posterior portion of the mesopleuron smooth (entirely striate in $T$. vanharteni), the entire metapleuron crenulate (ventrally smooth in T. vanharteni) and the ventro-posterior aspects of propodeum glabrous (densely setose in $T$. vanharteni).

Distribution. Southwestern Asia: Turkmenistan, Armenia. (Fig. 12)

Material examined. Non-type: ARMENIA: Sisian, 23.VI.1957, V. Tryapitsyn [collector] (label in Russian; locality data taken from Kovalev (1995)) (1 male). Deposited in ZMAS.

Note: The holotype specimen of T. popovi is in very poor condition. It was the opinion of O. Kovalev (pers. comm.) that the specimen best stay in St. Petersburg and not travel for further examination. Hence, the redescription here is based on conspecific material included in the original description of T. popovi.

Image deposition. A MorphBank collection of images of $T$. popovi can be accessed via http://morphbank.net/Show/?id=110338.

\section{Trjapitziniola vanharteni n. sp. Buffington \& van Noort}

(Fig. 11)

Description. FEMALE. Head. Shiny, shagreened around ocelli and on vertex (Fig. 11F); frons shagreened (Fig. 11F), cheeks smooth; setae present only on frons and occiput. Antenna entirely dark brown/black; scape $2 \mathrm{x}$ length of radicle, short appressed setae present on all 11 flagellomeres, filiform, last pair nearly fused.

Mesosoma. Entire pronotum striate, shiny, with few sparse, long setae (Fig. 11C); pronotal carina present dorsally, indistinct ventrally. Mesopleuron entirely striate; dorsal and ventral margins of mesopleural triangle clearly visible, glabrous anteriorly, weakly setose towards midpit (Fig. 11C). Mesoscutum entirely shiny (lacking microsculpture) with several scattered setae present over entire surface; notaulices complete, originating at anterior end of parascutal impression; area between posterior junction of notaulices delineated by elongate impression (Fig. 11D). Disk of scutellum anteriorly smooth, posteriorly strongly rugulose; disk distinctly angled midway, declined; declined area flat (Figs 11B and 11C). Posterior margin of disk strongly rugose, bordered by raised carina (Fig. 11B).

Metapleural-propodeal complex. Metapleuron glabrous except for sparse setae within the antero-ventral cavity (Fig. 11C), entirely rugose. Propodeum crenulate, long setae present (Figs 11C and 11D); area between propodeal carinae strongly carinate, glabrous. Nucha crenulate, not striate, protruding posteriorly. 


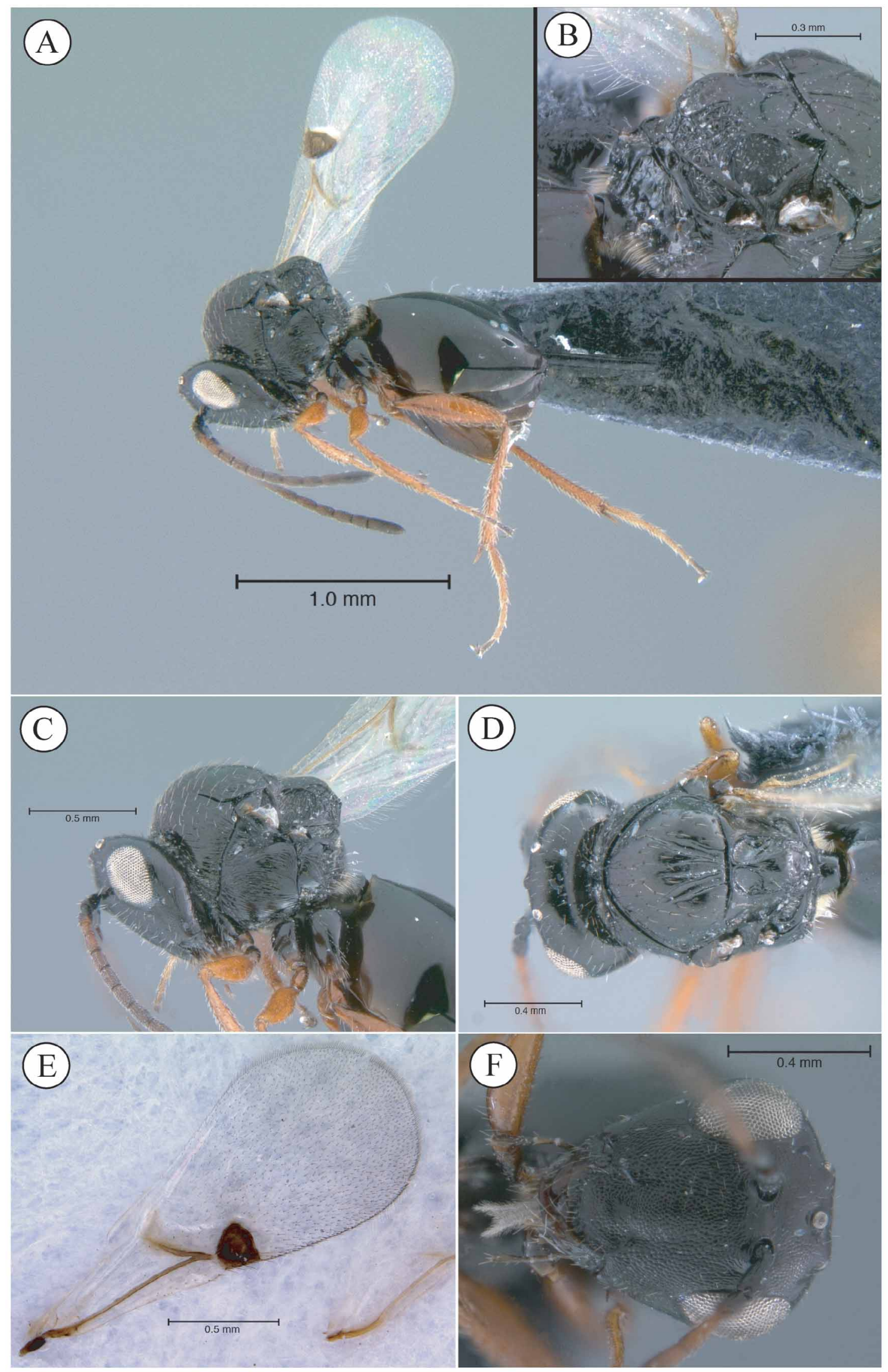

FIGURE 11. Trjapitziniola vanharteni Buffington \& van Noort, holotype specimen, female. A, habitus. B, scutellum, postero-dorsal view. C, head and mesosoma, lateral view. D, head and mesosoma, dorsal view. E, left forewing. F, head, anterior view. 
Metasoma. Petiole striate without visible setae; petiole obscured anteriorly by syntergum. Syntergum smooth and shiny, entirely glabrous (Fig. 10A). Entire metasoma, in lateral view, about as long as deep.

Wings. Pseudostigma weakly sclerotised, marginal cell clearly visible (Fig. 11E).

Legs. Coxae and femora setose, light brown to orange, non metallic; remaining portion of legs orange, non metallic; legs evenly covered with long, non appressed setae entirely to claws (Fig. 11A).

MALE. Unknown.

Diagnosis. Separated from $T$. popovi by having the scape $2 \mathrm{x}$ length of the radicle (1.25x length of radicle in T. vanharteni), posterior portion of the mesopleuron entirely striate (posteriorly smooth in T. popovi), having the ventral portion of the metapleuron smooth (crenulate in T. popovi) and having the ventro-posterior aspects of the propodeum setose (glabrous in T. popovi).

Etymology. Named for the collector, Anthony van Harten.

Distribution. Southwestern Asia: United Emirates Republic (Fig. 12).

Material examined. Holotype: UNITED EMIRATES REPUBLIC: Wadi Maidaq, 25.18N 56.07E, 29.III-10.IV.2006, in white \& yellow water traps, A. van Harten, coll. [first label], USNM type [second label]. The holotype is a female mounted on a black card point; the right fore and hind wings are mounted on a white card below the black point. The holotype is in good condition. Deposited in USNM.

Additional material. None.

Image deposition. A MorphBank collection of images of T. vanharteni can be accessed via http://morphbank.net/Show/?id=110337.

\section{Discussion}

The pycnostigmines exhibit an intriguing fragmented distributional pattern, comprising an element confined to the Cape Faunal Zone (Endrödy-Younga 1978) in the Afrotropical Region and a second element residing in the southern reaches of the western Palaeartic Region. These distributional patterns correspond with Mediterranean or desert habitat in semi-arid, temperate zones. Pycnostigmus is confined to the southern Afrotropical Region; Trjapitziniola to the western Palaearctic Region and Tylosema is represented in both areas. No pycnostigmine specimens have been collected in the Mesic intervening areas. Masarine wasps (Vespidae) also exhibit this biogeographical pattern (Gess 1992). Interestingly, 4 genera of masarine wasps are shared between the two areas; the Palaearctic Region has one endemic genus and the other three genera are endemic to southern Africa, suggesting a similar historical evolutionary driving process for both groups of wasps. The historical biogeography of these wasps was likely to have been driven by physiographical change affecting climate change, which in turn affected vegetation biome geography. Aridification of southern Africa commenced around 20 million years ago with the formation of the cold Benguela current upwelling system, which removed the moisture supply to the interior of the continent from the Atlantic Ocean. This was further enhanced by uplift of the continent, known as the African Super Swell, which increased the height of the eastern escarpment, further entrenching the east-west rainfall gradient (King 1978; McCarthy \& Rubidge 2005). Contemporary drier areas in the north and south of the African continent were linked in the past. For example, during a period of cooling in the middle Miocene 15.6-12.5 million years ago (Denton 1999), and during repeated interglacial periods of the Pleistocene epoch when forests in tropical Africa contracted considerably, forming refugia with a corresponding expansion of more xeric environments (Axelrod \& Raven 1978; Denton 1999). The historical distribution of pycnostigmines, as did the rest of the fauna exposed to these changes (Grubb 1999; Grubb et al. 1999; Vrba 1992), followed suite, experiencing phases of being alternately continuous and disjunct, culminating in the current phase of vicariance dictated by habitat and environment. This arid adapted vicariance is evident in a number of contemporary faunal distributions, such as butterflies (Carcasson 1964), masarine wasps (Gess 1992), flies (Bowden 1978), mammals (Grubb et al. 1999) and plants 
(White 1983).

Biogeographical generic affinities and endemism of extant pycnostigmines may support the vicariance hypothesis, rather than one of dispersal. If we, however, examine phylogenetic relationships there are three possible hypotheses. Either a relationship in which the endemic Palaearctic genus is basal (Trjapitziniola (Tylosema, Pycnostigmus)) suggesting a Laurasian origin, or one in which the endemic Afrotropical genus is basal (Pycnostigmus (Trjapitziniola, Tylosema)), suggesting a Gondwanan origin. The third possibility, where Tylosema is basal, would invoke a relatively recent (in the last 15 million years) vicariance event and subsequent evolution of Pycnostigmus and Trjapitziniola. Though the chronogram in Buffington (2005) did not include Pycnostigminae, the dating of the divergences of major lineages of Figitidae reported in that paper occurred between 73-89 million years ago. Thus, the third scenario listed above is unlikely.

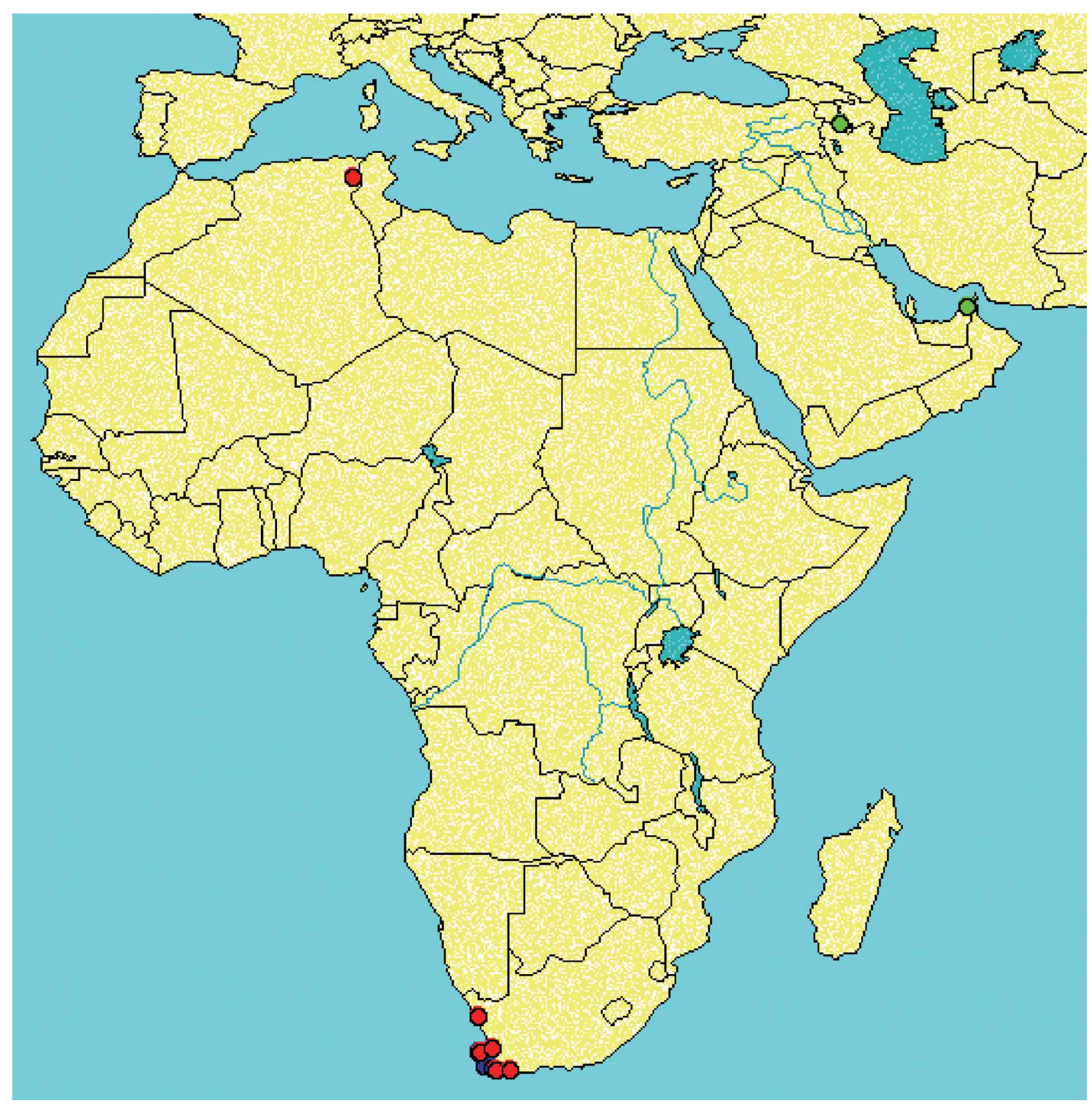

FIGURE 12. World distribution map of Pycnostigminae. Green dots: Trjapitziniola; red dots: Tylosema; blue dots: Pycnostigmus. 


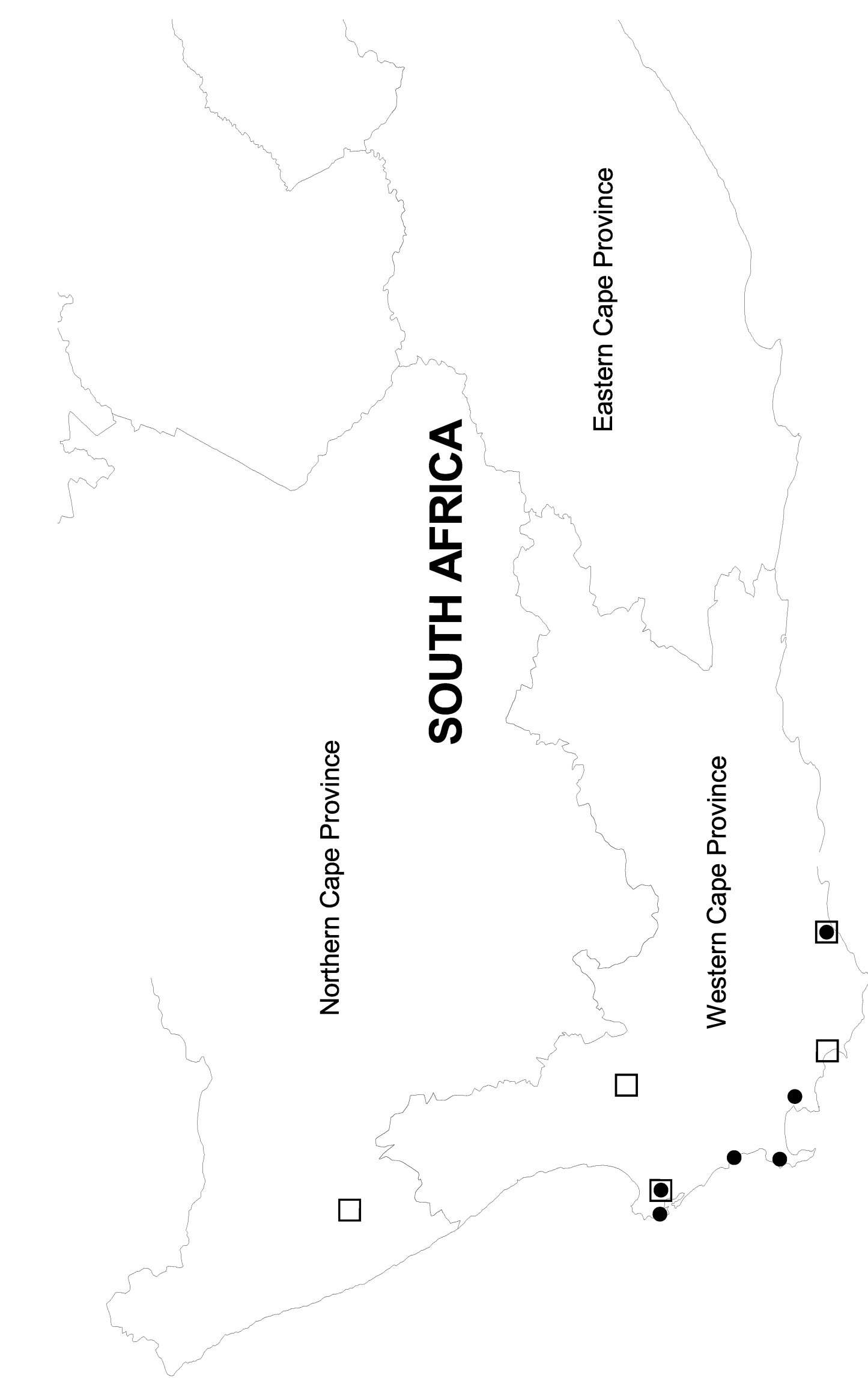

FIGURE 13. Distribution map of South African Pycnostigmus and Tylosema species. Solid dots: Pycnostigmus; open squares: Tylosema. 
We feel that a holistic appraisal of contemporary biogeographical evidence strongly supports a hypothesis of dispersal from the western Palaearctic with subsequent vicariance in Africa. This points towards a Laurasian origin with Trjapitziniola basal and the Tylosema+Pycnostigmus clade derived. Buffington's (2005) chronogram for figitid-cynipid divergence estimates reflects a pattern that supports a Laurasian origin of proto microcynipoids (early cynipids and figitids), now represented by the Mediterranean Parnips, which provides some support for the latter hypothesis. This split has been estimated to have occurred between 83-90 million years ago (Buffington 2005). Until rigorous phylogenetic hypotheses are available for Pycnostigminae, biogeographic patterns for this group will remain tantalizingly out of reach.

The absence of pycnostigmines from Australia and South America, as well as Madagascar, is intriguing. Possibly they still remain to be discovered in these regions. This is not unlikely given that the South African pycnostigmine fauna was only known from two specimens until fairly recently (1994), from which time concerted collecting efforts in the Western Cape uncovered a "reasonably" rich fauna. An assumption that pycnostigmines are only present in South Africa in the southern hemisphere suggests a non-Gondwanan origin (barring the less parsimonious hypothesis embracing dual extinction events in South America and Australia).

The South African Pycnostigminae appear to be restricted to the Western Cape and Northern Cape Provinces, where the species are associated with the Cape Faunal zone (Endrödy-Younga 1978) including the Cape Floral Kingdom and Nama Karoo habitats. The region has been recognized as a globally important biodiversity hotspot (Myers et al. 2000; Latimer 2005), as well as a center of distribution and endemism for plants (Cowling et al. 1998) and numerous invertebrate taxa, including the recently discovered insect order Mantophasmatodea (Picker et al. 2002). Pycnostigminae may have, as has a clade of dwarf chameleons (Tolley et al. 2006), diversified at the species level with the evolution and radiation of the Cape Floristic Region 3-5 million years ago (Goldblatt 1997; Linder et al. 1992; Linder 2003).

Distribution data and habitat association for South African pycnostigmines suggests a degree of habitat dependence. Pycnostigmus rostratus, P. mastersonae, P. incognito and P. fossilensis have a recorded association with West Coast Strandveld and Sand Plain Fynbos, a threatened habitat restricted to low altitude regions in the southwestern area of the Western Cape Province. The holotype and paratype specimens of P. rostratus were collected in Cape Town one hundred years ago. Although the collection data has no reference to habitat, historically the lowland habitat in this region was primarily comprised of Sand Plain Fynbos, which has over the intervening period been destroyed by development and urban sprawl. Recent specimens have all been collected in either West Coast Strandveld or Sand Plain Fynbos that still occurs north of Cape Town. Pycnostigmus hoerikwaggoensis has only been collected at higher altitude (460-520m) in Mesic Mountain Fynbos. This species may be restricted to this habitat. Tylosema dayae has a wider habitat tolerance being associated with Sand Plain Fynbos, South Coast Strandveld, riverine vegetation and Upland Succulent Karoo. Together, these data suggest that the Pycnostigmus species and Tylosema ronquisti, which has only been recorded from Sand Plain Fynbos, may have a wider distribution than currently recorded. Our observed distribution records are likely to be an artifact of under-sampling and it is probably premature to provide too much conjecture about habitat association before further collecting in unsampled habitats and areas has been undertaken.

All of the South African pycnostigmine specimens were collected during the period encompassing August to October. Three of the localities were surveyed throughout all seasons using the same trapping methods, suggesting that adults of Pycnostigmus and Tylosema species only emerge during the Spring in the southern hemisphere.

We expect that further pycnostigmine species will be revealed on further sampling in western South Africa and possibly southern Namibia. Implementation of comprehensive sampling regimes in the hotter, drier southern areas of the Western Palaearctic Region will probably reveal a relatively rich fauna, at least one that parallels the species richness in South Africa. The relatively recent (in the last 12 years) collection of the majority of pycnostigmine species ( 7 of 10) underlines the urgent need to employ diverse and efficient methods to sample invertebrate fauna across all habitats. 


\section{Acknowledgements}

MLB is grateful to Fred Ronquist for encouragement and partial financial support (through NSF, below) for this project. Shelah Morita (UCD), Michael Pogue (SEL), Tom Henry (SEL) and Krystal Tolley (SANBI) provided useful comments on the text. Jennifer Day (UCT) provided residence for MLB while this research was conducted. Cape Nature provided collecting permits: No. 205/96 and 288/1999. We thank Gert Greef for granting permission to collect in Koeberg Nature Reserve, and also the staff of the West Coast Fossil Park for their assistance. We thank the curators listed in the text for making type and non-type specimens available for our examination, as well as Alex Konstantinov (SEL) for transporting the specimen of Trjapitziniola popovi used in this study. Ted Shultz (USNM, Smithsonian Institution) allowed MLB access to his lab's Auto-montage system for imaging Trjapitziniola popovi and Tr. vanharteni. Katja Seltmann (FSU) assisted MLB with setting up the MorphBank links. MLB was partially funded by the NSF Assembling the Tree of Life Grant EF-0337220 and by the Systematic Entomology Lab, USDA/ARS. SVN was funded by the National Research Foundation Italy-South Africa agreement under Grant GUN 2068865. We also acknowledge MorphBank (http://www.morphbank.net), Florida State University, School of Computational Science, Tallahassee, FL 32306-4026 USA.

\section{References}

Axelrod, D.I. \& Raven, P.H. (1978) Late Cretaceous and Tertiary vegetation history of Africa. In: Werger, M.A.J. (Ed.), Biogeography and Ecology of Southern Africa, W. Junk, The Hague, pp. 77-130

Belizin, V.I. (1951) Cynipidae (Hymenoptera) of the fauna of the USSR and adjacent countries [In Russian]. Entomologicheskoe Obozrenie, 31, 566-574.

Bowden, J. (1978) Diptera. In: Werger, M.A.J. (Ed.), Biogeography and Ecology of Southern Africa, W. Junk, The Hague, pp. 775-796

Buffington, M. (2000) The phylogeny and classification of the Gronotoma group (s.l.) of genera (Hymenoptera: Figitidae: Eucoilinae). Texas A\&M University. [MS Thesis].

Buffington, M. (2005) Phylogenetics and evolution of the Figitidae (Hymenoptera: Cynipoidea). University of California, Riverside. [Doctoral Dissertation].

Buffington, M.L., Burks, R.\& McNeil, L. (2005) Advanced techniques for imaging microhymenoptera. American Entomologist, 51, 50-54.

Cameron, P. (1905) A new genus and species of Cynipidae from South Africa, representing a new subfamily. Annals and Magazines of Natural History, Series 7, 16, 20-21.

Carcasson, R.H. (1964) A preliminary survey of the zoogeography of African butterflies. East African Wildlife Journal, $2,122-157$.

Cowling, R.M., Rundel, P.W., Desmet, P.G., \& Esler, K.J., (1998) Extraordinarily high regional-scale plant diversity in southern African arid lands: subcontinental and global comparisons. Diversity and Distributions, 4, 27-36.

Denton, G.H. (1999) Cenozoic climate change. In: Bromage, T.G. \& Schrenk, F. (Eds.) African Biogeography, Climate Change and Human Evolution, Oxford University Press, Oxford, UK, pp. 94-114.

Endrödy-Younga, S. (1978) Coleoptera. In: Werger, M. A. J. (Ed.) Biogeography and Ecology of Southern Africa, W. Junk, The Hague, pp. 799-820.

Fleming, I. (1959) Goldfinger, New York, Macmillan, 191 pp.

Fontal-Cazalla, F.M., Buffington, M., Nordlander, G., Liljeblad, J., Ros-Farré, P., Nieves-Aldrey, J. L., Pujade-Villar, J., \& Ronquist, F. (2002) Phylogeny of the Eucoilinae (Hymenoptera: Cynipoidea: Figitidae). Cladistics, 18, 154-199.

Gess, S.K. (1992) Biogeography of the masarine wasps (Hymenoptera: Vespidae: Masarinae), with particular emphasis on the southern African taxa and on correlations between masarine and forage plant distributions. Journal of Biogeography, 19, 491-503.

Goldblatt, P. (1997) Floristic diversity in the Cape Flora of South Africa. Biodiversity and Conservation, 6, 359-377.

Grubb, P. (1999) Evolutionary processes implicit in distribution patterns of modern African mammals. In: Bromage, T.G. \& Schrenk, F. (Eds.) African Biogeography, Climate Change and Human Evolution, Oxford University Press, Oxford, UK, pp. 150-164.

Grubb, P., Sandrock, O., Kullmer, O., Kaiser, T.M. \& Schrenk, F. (1999) Relationships between eastern and southern African mammal faunas. In: Bromage, T.G. and Schrenk, F. (Eds.) African Biogeography, Climate Change and 
Human Evolution, Oxford University Press, Oxford, UK, pp. 253-267.

Harris, R.A. (1979) A glossary of surface sculpturing. Occasional Papers in Entomology, 28, 1-31.

International Commission on Zoological Nomenclature (2000) International Code of Zoological Nomenclature. C/o The Natural History Museum, Cromwell Road, London SW7 5BD, UK. Available from: www.iczn.org (accessed 6 May 2006)

Kieffer, J.J. (1905) Description de quelques Hyménoptères exotiques. Bulletin de la Societé Histoires Naturelles de Metz, 24, 85-114.

King, L. (1978) The geomorphology of central and southern Africa. In: Werger, M. A. J. (Ed.) Biogeography and Ecology of Southern Africa, W. Junk, The Hague, pp. 1-17.

Kovalev, O. (1995) Paleontogical history, phylogeny, and the system of brachycleistograstromorphs and cynipomorphs (Hymenoptera: Brachycleistograstromorpha infraorder n., Cynipomorpha infraorder $\mathrm{n}$.) with description of new fossil and recent families, subfamilies and genera. Entomological Review, 74, 105-147. (Originally published in Russian in Entomologicheskoe Obozrenie, 73, 385-426).

Latimer A.M., Silander, J.A. \& Cowling, R.M. (2005) Neutral ecological theory reveals isolation and rapid speciation in a biodiversity hot spot. Science, 309, 1722-1725.

Linder H.P. (2003) The radiation of the Cape flora, southern Africa. Biological Reviews, 78, 597-638.

Linder H.P., Meadows, M.E. \& Cowling, R.M. (1992) History of the Cape flora. In: Cowling R.M. (Ed.) The Ecology of Fynbos, Nutrients, Fire and Diversity. Oxford University Press, Oxford, UK, pp. 113-134.

McCarthy, T. \& Rubidge, B. (2005) The story of Earth \& Life. A southern African perspective on a 4.6-billion-year journey. Struik Publishers, Cape Town, 336 pp.

Myers N., Mittermeier, R.A., Mittermeier, C.G., da Fonseca, G.A.B. \& Kent, J. (2000) Biodiversity hotspots for conservation priorities. Nature, 403, 853-858.

Picker, M.D., Colville, J.F. \& van Noort, S. (2002) Mantophasmatodea now in South Africa. Science, $297,1475$.

Rasnitsyn, A.P. (1980) [Origin and evolution of Hymenoptera]. Trudy Paleontologicheskogo Instituta Akademiya Nauk SSSR, 123, 1-196 [in Russian].

Ronquist, F. (1995) Phylogeny and early evolution of the Cynipoidea (Hymenoptera). Systematic Entomology, 20, 309335.

Ronquist, F. (1999) Phylogeny, classification and evolution of the Cynipoidea. Zoologica Scripta, 28, $139-164$.

Tolley, K.A., Burger, M., Turner, A.A. \& Matthee, C.A. (2006) Biogeographic patterns and phylogeography of dwarf chameleons (Bradypodion) in an African biodiversity hotspot. Molecular Ecology, 15, 781-793.

Vrba, E.S. (1992) Mammals as a key to evolutionary theory. Journal of Mammalogy, 73, 1-28.

Weld, L. (1952) Cynipoidea (Hym.) 1905-1950. Privately Printed, Ann Arbor, Michigan, 350 pp.

White, F. (1983) The vegetation of Africa. A descriptive memoir to accompany the Unesco/AETFAT/UNSO vegetation map of Africa, Unesco, Paris, 356 pp. 